Article

\title{
Long-Term Water Quality Patterns of a Flow Regulated Tropical Lowland River
}

\author{
Lizaan de Necker ${ }^{1, *(\mathbb{D})}$, Tinyiko Neswiswi ${ }^{2}$, Richard Greenfield ${ }^{2}$, Johan van Vuren ${ }^{1}{ }^{(\mathbb{D}}$, \\ Luc Brendonck ${ }^{1,3}$, Victor Wepener ${ }^{1}\left(\mathbb{D}\right.$ and Nico Smit ${ }^{1}$ (I) \\ 1 Water Research Group, Unit for Environmental Sciences and Management, North-West University, \\ Private Bag X6001, Potchefstroom 2520, South Africa; jjvvuren@gmail.com (J.v.V.); \\ luc.brendonck@kuleuven.be (L.B.); victor.wepener@nwu.ac.za (V.W.); nico.smit@nwu.ac.za (N.S.) \\ 2 Department of Zoology, University of Johannesburg, Auckland Park 2006, South Africa; \\ MpeteT@dws.gov.za (T.N.); rgreenfield@uj.ac.za (R.G.) \\ 3 Animal Ecology, Global Change and Sustainable Development, Department of Biology, \\ University of Leuven, 32 Charles Deberiotstraat, 3000 Leuven, Belgium \\ * Correspondence: lizaan.denecker@gmail.com
}

Received: 4 November 2019; Accepted: 13 December 2019; Published: 20 December 2019

\begin{abstract}
Floodplain ecosystems in Africa are under threat due to direct anthropogenic pressure and climate change. The lower Phongolo River and associated floodplain is South Africa's largest inland floodplain ecosystem and has been regulated by the Pongolapoort Dam since the 1970s. The last controlled flood release from the dam occurred in December 2014, after which a severe drought occurred and only a base flow was released. The central aims of this study were to determine the historic and present water quality state of the middle and lower Phongolo River and assess the possible effects of the most recent drought may have had. Historic water quality data (1970s to present) were obtained from monitoring stations within the Phongolo River catchment to assess the long-term water quality patterns. Using multivariate statistical analyses as well as the Physicochemical Driver Assessment Index (PAI), a water quality index developed for South African riverine ecosystems, various in situ and chemical water variables were analysed. Key findings included that the water quality of the middle and lower Phongolo River has degraded since the 1970s, due to increased salinity and nutrient inputs from surrounding irrigation schemes. The Pongolapoort Dam appears to be trapping nutrient-rich sediments leading to nutrient-depleted water entering the lower Phongolo River. The nutrient levels increase again as the river flows through the downstream floodplain through input from nutrient rich soils and fertilizers. The drought did not have any significant effect on water quality as the PAI remained similar to pre-drought conditions.
\end{abstract}

Keywords: anthropogenic effects; drought; dams; floodplain system; sediment retention; salinization; Southern Africa; South Africa

\section{Introduction}

Numerous causes exist that may change or degrade river water quality [1]. These include natural processes such as natural high and low flows and weathering of soils and rock, and/or human activities such as the construction of dams and the discharge of industrial and domestic wastewater, as well as agricultural drainage [2-4]. These phenomena can be exacerbated by climatic conditions such as drought, one of the most prominent effects of which is reduced flow, which places additional stress on freshwater ecosystems already impacted by human activities $[5,6]$.

Although the construction of dams is a necessity that supplies water for agricultural, industrial and domestic use, it is well documented that dams have the potential to cause severe negative 
impacts on the environment, as well as on the biophysical characteristics of a river both downstream and upstream of the impoundments [7-10]. Effects include altering the magnitude and velocity of floods and river flows either upstream or downstream of the dam [11], sediment trapping within the impoundment $[10,12,13]$, loss of fertile topsoil downstream of the dam $[8,14]$, nutrient retention within the impoundment [13], nutrient loading downstream of the dam and loss of biodiversity, particularly fish and macroinvertebrates $[9,15,16]$. The type and magnitude of these effects may differ between systems and is highly dependent on the size of the dam, whether hyper- or hypolimnetic discharge occurs, the purpose for which it was built, the type of river it is located on and the natural variability and function of rivers $[12,17,18]$. Through controlled flooding regimes, water may be released from an impoundment in a variety of patterns that differ from the natural hydrological regime of a river and thus impacts on the downstream ecosystem [12,19-21], the most prominent impact being reduced downstream flow $[8,22]$. Reduced river discharge may result in a reduced flooding area and environmental flow, leading to variation in natural abiotic and biotic processes [23] such as nutrient cycling and the migration and spawning of fish $[8,24]$.

Low-flow drought disturbances are either seasonal or supra-seasonal [25] and may further exacerbate the effects already present in regulated and anthropogenically utilised rivers. Seasonal droughts are disturbances in the environment that occur on a regular, predictable basis and, when accompanied by regular floods, have been proven to enhance the productivity of an ecosystem (e.g., the Flood-Pulse concept formulated by Junk et al. [26,27]. Conversely, supra-seasonal droughts are thought of as ramps in nature (disturbances that increase in strength and spatial extent over time) and are the result of declined rainfall over an extended period, usually several seasons [28,29]. These types of drought have already increased in frequency and intensity in many regions worldwide, most prominently in semi-arid countries such as Australia and southern Africa [30-32]. Most current knowledge regarding the effects of and biotic responses to drought arise from studies in temporary wetlands and predictable seasonal droughts, while less has been accomplished on the effects that an unpredictable supra-seasonal drought may have on ecosystems associated with regulated rivers $[25,33]$. When combined with human activities such as the overexploitation of resources, water pollution, habitat destruction, water abstraction, dams and regulated discharge, the impact of drought and the potential ecological changes thereof become more uncertain $[25,30]$. In addition to these issues and a lack of knowledge, a review by Mosley [32] revealed that very little published information is available regarding the impact of drought on water quality in Africa.

Agriculture has both direct and indirect effects not only on surface but also groundwater quality and is one of the principal causes of water quality degradation, particularly in rural areas $[1,34]$. Sources of pollution associated with agriculture (agro-pollutants) include livestock, nitrate- and phosphate-rich fertilizers, metals, pathogens, pesticides, irrigation and the removal of natural habitats for farms and plantations [1,34]. Agro-pollutants may cause both acute and long-term degradation and change in water quality and the aquatic community [34]. South Africa has a well-developed commercial agricultural industry, as well as subsistence agricultural activities predominantly in rural areas [34], and many of these occur in close proximity to rivers and dams. The Phongolo River is a prime example of this, as the largest part of its catchment is covered by forestry plantations, commercial and subsistence farming [35] as well as pivot irrigation (water sprinkler irrigation with a central pivot system; [36]). The Phongolo River is also a cross-border river, as it is shared with Mozambique, and is important to both countries [35]. Careful monitoring of water quality over long-and short-term periods of such cross-border systems is not only ecologically but also politically important [37].

For efficient management, and to minimize impacts on downstream water quality and ecological functions and services (which may support both environmental and human health and wellbeing), it is important to maintain the ecological integrity of an ecosystem $[4,8,38]$. An aspect of ecological integrity assessment includes the monitoring and analysis of spatio-temporal patterns in the abiotic and biotic water quality of a river. Traditionally, this has been accomplished based on spot water samples and a comparison with existing experimentally determined guidelines [39] such as the Target Water 
Quality Guidelines (TWQG) created by the Department of Water Affairs and Forestry (DWAF) for South African aquatic ecosystems [40]. Although useful, spot water samples only provide a momentary indication of water quality with no clear long-term trends or changes in chemical concentrations [41]. Experimentally determined guidelines also do not provide a holistic view of the spatial, seasonal or historic trends or variations in the studied waterbody [42]. Long-term data are therefore essential to establish a baseline of water quality and to evaluate the effects of natural and anthropogenic induced changes in water resources [38]. Such data sets also indicate long-term changes in catchment responses and may contain evidence of rare events (e.g., severe droughts or floods) or rapid shifts in the system's behaviour [43-45]. Globally, studies have made use of long-term data in order to assess changes in river water quality including nitrate fluxes [46], hydrology [38], the effects of agriculture [47], the impact of reservoir construction on downstream flow regime [9] and the effects of land use changes [48]. In addition, the use of multivariate approaches and water quality indices, such as the Physicochemical Driver Assessment Index (PAI), allows for the interpretation of complex data sets in order to better understand the quality and ecological status of a studied ecosystem [3]. Multivariate analysis enables the discovery of possible drivers that may be influencing water quality and easily identifies and interprets water trends $[49,50]$. Simultaneously, water quality indices ascribe a unitless qualitative value to an aggregate set of measured variables and is based on a set of scientifically determined criteria [50]. The PAI is a water quality index developed for South African riverine ecosystems in order to determine the state of the physical and chemical water quality for a resource unit or a specific site [51-53].

In riverine systems associated with floodplains, increased water usage for irrigation reduces the total water supply and groundwater recharge further downstream. This may lead to a drop in the water table, diminishing the extent of the active floodplain, causing salinization and potentially invasion by exotic species [8]. Salinization may be further exacerbated through decreased natural flow and drought, which increases the total dissolved solids (TDS) and conductivity and changes the ionic composition [54-56]. Many large floodplain systems in Africa are still unstudied and in a relatively natural state, but due to water management strategies such as the construction of dams, irrigation schemes and improperly managed flood release, these systems are under severe pressure [23]. This is certainly the case for the Phongolo floodplain. This is South Africa's largest inland floodplain system, and it is under threat due to land use, water abstraction [57] and, more recently, a severe supra-seasonal drought $[58,59]$. The floodplain is dependent on water from annual controlled flood releases from the Pongolapoort Dam, completed in 1973, located upstream of the floodplain [20]. Although guidelines suggesting the volume, frequency, duration and timing of the flood were proposed in the 1970s-1980s [60,61], these have not been implemented. In addition, at the time of the present study between 2016 and 2017, South Africa was in the grips of the most severe supra-seasonal drought the country had experienced in 23 years [59], and therefore no floods had been released from the Pongolapoort Dam for two years.

Water quality data have been collected across South Africa since the early 1970s. A substantial amount of analytical data are available for the for the Phongolo River in northern KwaZulu-Natal dating back to the early 1970s, due to regular assessments of monitoring stations and the completion of a water quality study on the system [62]. Possible impacts of the agricultural developments surrounding Pongolapoort Dam and the upper Phongolo River have been mentioned in previous assessments of the area (e.g., [35,63-65]). However, these studies largely focused on the middle and upper reaches of the catchment and there is still a lack of summarizing studies considering long-term analysis of the river itself, particularly in its downstream region. This includes determining the possible long-term effects of the dam and agricultural activities, assessing potential changes as a result of increased human activity, and the effects of drought on this ecologically and economically important river. This information is critical for determining sustainability and biodiversity conservation within the ecosystem. Concerns have also been raised regarding not only the effect of the flood releases on the downstream ecosystem, which 
is still poorly understood, but also the human activities occurring on the floodplain and in the upper reaches of the river's catchment.

The central aim of this study was to assess the historical water quality of the middle and lower Phongolo River and determine the trends and potential changes in water quality variables from the 1970s to 2017. A second aim was to determine whether the Pongolapoort Dam has had any effect on water quality of the lower Phongolo River. The final aim was to ascertain whether the most recent severe supra-seasonal drought experienced from 2015 to 2017 led to changes in the water quality of the Phongolo River. These aims were achieved by assessing chemical water quality variables collected from the Department of Water and Sanitation's monitoring stations along the middle and lower Phongolo River from 1972 to 2017. Multivariate statistical analyses and PAI were used to compare collected water quality variables above and below the Pongolapoort Dam as well as between historic, pre-drought and drought conditions. Four hypotheses were tested as part of this study: (1) Water quality of the middle and lower Phongolo River has deteriorated since the 1970s due to increased anthropogenic stressors and will be represented by changes in the studied water quality variables and a corresponding decrease in the PAI score of all sites. (2) Owing to historic overuse, the quality of water entering the Pongolapoort Dam from the middle Phongolo River is in a poor state and will be represented by a low PAI score. (3) The Pongolapoort Dam has reduced the quality of water entering the lower Phongolo River and this will be reflected by a lower PAI score below the dam than above the dam. (4) The supra-seasonal drought experienced between 2015 and 2017 negatively affected water quality of the middle and lower Phongolo rivers and caused a further decline in the PAI scores from pre-drought to drought conditions.

\section{Materials and Methods}

\subsection{Study Area}

The upper Phongolo River originates in Mpumalanga, South Africa, flowing towards the eastern part of the country where it is joined by the Bivane River before flowing through the Lebombo and Ubombo mountain ranges into northern KwaZulu-Natal $[63,65,66]$. Hereafter, the middle Phongolo River flows through the town of Pongola, where it widens into the intensely cultivated Lowveld area, finally flowing into the Pongolapoort Dam $([65,67]$, Figure 1). The Pongolapoort Dam, completed in 1973, was built with the key purpose of supplying enough water to irrigate 40,000 to 50,000 ha of cultivated land (mostly sugarcane) in the highly fertile area adjacent to the Phongolo floodplain [68]. Before the construction of the Pongolapoort Dam, summer flooding inundated the floodplain, creating a mosaic of environments for the aquatic biota of the area and provided a source of protein to the local people in the form of fish. The possible effects and recommended flood release strategies were researched before the construction of the Pongolapoort Dam (e.g., [63,69-71]) and by the time the dam was completed, a detailed flooding regime had been determined that would mimic the natural floods, sustain the ecological integrity of the floodplain and continue to provide services to the people in the region with minimal effects on the irrigation schemes [68] (see $[60,61]$ for a full description). However, due to unforeseen circumstances such as the drought of 1981 to 1983 (indicated by arrows in Figure 2) and the Domoina cyclone of 1984 (see [64]), the proposed flooding regime was difficult to implement. More than 40 years later, there is still no proper management of the dam and its release.

The lower Phongolo River and the associated floodplain starts below the Pongolapoort Dam, stretching approximately $80 \mathrm{~km}$ downstream to the confluence of the Phongolo and Usuthu rivers at the international border with Mozambique within the conservation area of Ndumo Game Reserve (NGR). It is South Africa's largest riverine floodplain, with an area of $120 \mathrm{~km}^{2}$ [66,72]. Approximately $40 \%$ of the floodplain lies in South Africa, while the remaining 60\% is found in Mozambique, forming part of the Rio Maputa River floodplain [20,73,74]. Ndumo Game Reserve is the only protected region of the Phongolo River and floodplain. Many endangered, rare and endemic species are found in the floodplain area, most of which are highly dependent on the river and the numerous temporary, 
permanent and floodplain associated wetlands [61,75]. Even though NGR is considered such an ecologically important region, it is severely under threat, as it is surrounded by both subsistence and commercial agriculture. A large agricultural irrigation scheme also operates upstream of the reserve in its catchment area [74]. The eastern part of the reserve is also utilized by the local community as a farming area and local people fish in the river within NGR and actively abstract water from the river for their crops as well (pers. observation; [66], Figure 1).

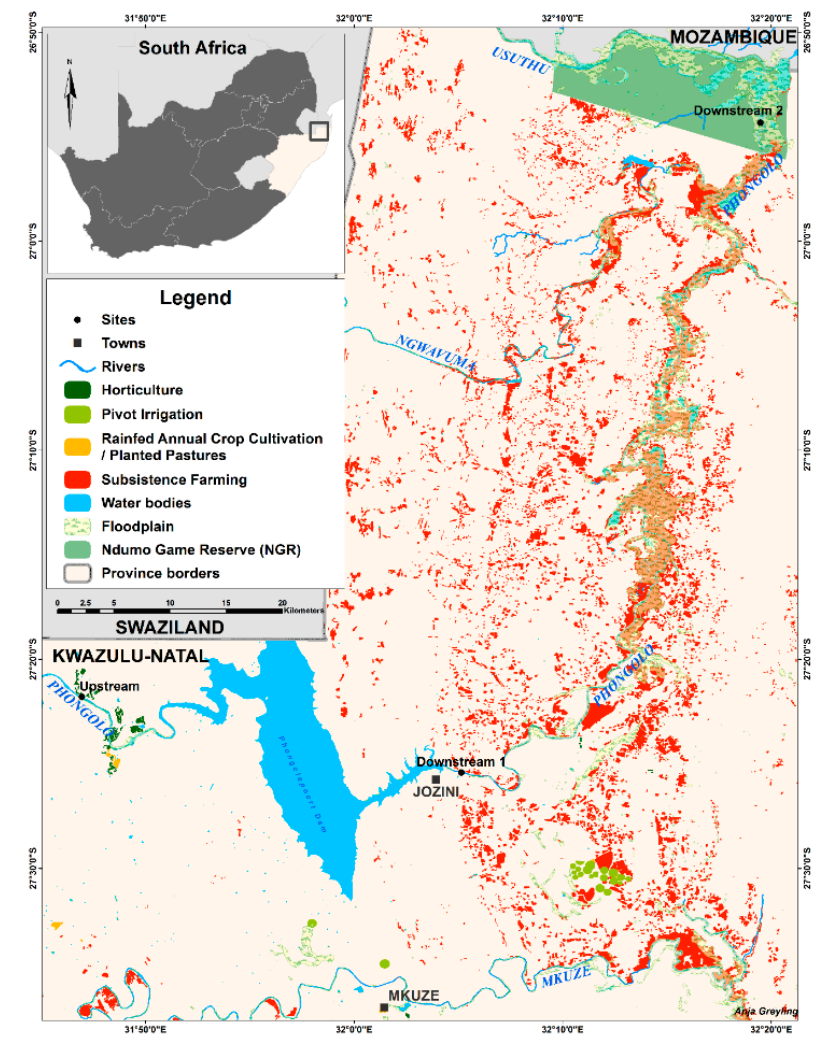

Figure 1. Map of the Pongolapoort Dam and lower Phongolo region indicating various irrigation schemes and farms located along the middle and lower Phongolo River as well as the three Department of Water and Sanitation (DWS) monitoring stations located on the Phongolo River above (Upstream) and below (Downstream 1 and Downstream 2) Pongolapoort Dam.

Although the lower Phongolo has largely been utilised by small scale subsistence farms for the past few hundred years [65,68], larger irrigation schemes have developed in recent years ([57], Figure 1). Threats to the upper reaches of the Phongolo River include abandoned coal mines in the Paulpietersburg area where the Bivane River originates, and an estimated $199 \mathrm{~km}^{2}$ and $480 \mathrm{~km}^{2}$ of irrigated and afforested area respectively [65]. The middle reaches of the Phongolo River are utilised by some 16,000 ha of sugarcane and 1000 ha of citrus, mango and vegetable farms. Water from the upper Phongolo River is reserved for these various land uses as well as for the Impala Irrigation Scheme in the middle Phongolo [65]. In addition, the Bivane Dam, located on the Bivane River upstream of its confluence with the Phongolo River, was completed in 1995 to provide additional irrigation water to the surrounding sugarcane farms and has also decreased the water inflow into the Pongolapoort Dam [61]. Presently, under normal circumstances, two controlled floods are released from the dam, the largest of which generally occurs in October, while a smaller release occurs around July (Figure 2). The main goal of this flooding regime is to meet socio-economic demands [58,61]. Three droughts have occurred in South Africa between 1972 and 2017. The first took place in 1983 [64], the second from 1991 to 1993 [76,77] and the most recent from 2015 to 2017 [59] (Figure 2). During these periods, the flow of the Phongolo River was greatly reduced and, in the cases of the droughts of 1983 and 2015-2017, 
no flood releases occurred from the Pongolapoort Dam. The drought of 1983 ended when a severe cyclone (cyclone Domoina) caused the biggest flood ever recorded in the Phongolo River between 29 January and 2 February 1984 [64]. During the drought of 1991 to 1993, normal flood releases still took place. The most recent drought from 2015 onwards is considered the worst that South Africa has experienced in 23 years, caused by a combined effect of a drought and a strong El Niño event [59] and the country is still experiencing the effects thereof. The last controlled flood release from the Pongolapoort Dam took place in December 2014. However, the system still receives a monthly baseflow that is continuously released as a result of the "compensation flows" agreement with Mozambique and is intended to be no less than $5 \mathrm{~m}^{3} \mathrm{~s}^{-1}$ [60].

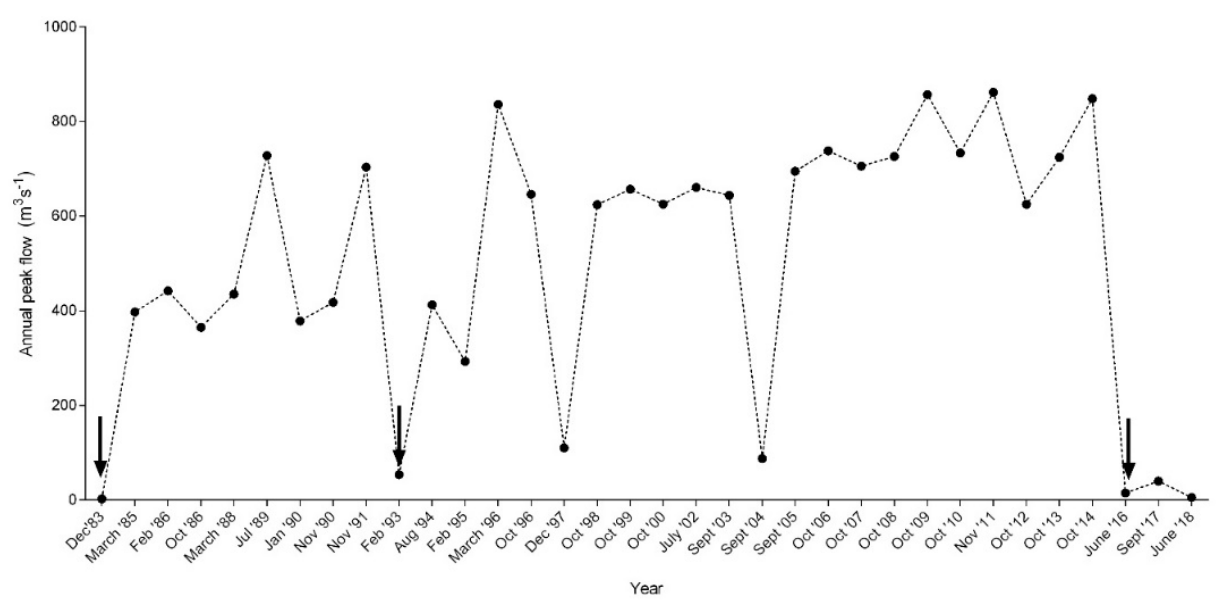

Figure 2. Annual peak flows of Phongolo River downstream of dam measured from 1983 to 2018. Arrows indicate peak years of severe droughts in 1983, 1993 and 2016 (available from https://www. dwaf.gov.za/Hydrology/Verified/hymain.aspx. Accessed on 4 June 2019).

\subsection{Data Collection}

Historical data from three South African Department of Water and Sanitation (DWS) monitoring stations within the Phongolo River catchment were obtained from the DWS National Chemical Monitoring Programme. The first of these selected monitoring stations, W4H006, Phongolo River (Upstream) is located upstream of Pongolapoort Dam, and the remaining two are located downstream of the dam. Station W4H013 (Downstream 1) is located below the dam wall and the final monitoring station (W4H009, Downstream 2) is located $80 \mathrm{~km}$ downstream of the dam within Ndumo Game Reserve (NGR) (Figure 1; Table 1). The water quality data collected and analysed from the monitoring stations included calcium $(\mathrm{Ca})$, chloride $\left(\mathrm{Cl}^{-}\right)$, conductivity $\left(\mu \mathrm{S} \mathrm{cm}{ }^{-1}\right)$, potassium $(\mathrm{K})$, magnesium $\left(\mathrm{Mg}^{+}\right)$, sodium $(\mathrm{Na})$, ammonium nitrogen $\left(\mathrm{NH}_{4}{ }^{+}-\mathrm{N}\right)$, nitrate nitrogen/nitrite nitrogen $\left(\mathrm{NO}_{3}{ }^{-}-\mathrm{N} / \mathrm{NO}_{2}{ }^{-}-\mathrm{N}\right), \mathrm{pH}$, orthophosphate $\left(\mathrm{PO}_{4}{ }^{3-}\right)$ and sulphates $\left(\mathrm{SO}_{4}{ }^{2-}\right)$. Historical data collected from the DWS database for the three sites are indicated in Table 1, along with the years for which data were available, and included years during which severe droughts occurred (1983, 1991 and 2015-2016). The monthly average flow data (measured in $\mathrm{m}^{3} \mathrm{~s}^{-1}$ ) were also obtained from Downstream 1 for the years 1985-2017.

Table 1. Department of Water and Sanitation (DWS) monitoring station numbers, names, locations, and years for which water quality data are available for the Phongolo River. All water quality variables for each monitoring station are presented as Supplementary Information (Tables S1-S3).

\begin{tabular}{ccc}
\hline River Region & DWS Monitoring Station Number and Location & $\begin{array}{c}\text { Years for Which Historical Data } \\
\text { Are Available }\end{array}$ \\
\hline Upstream (Middle Phongolo River) & W4H006 (Upstream, Phongolo River at Makanes Drift) & $1972-2017$ \\
\hline \multirow{3}{*}{ Downstream (Lower Phongolo River) } & $\begin{array}{c}\text { W4H013 (Downstream 1, Phongolo River immediately below } \\
\text { Pongolapoort Dam) W4H009 (Downstream 2, Phongolo River } \\
\text { within Ndumo Game Reserve) }\end{array}$ & $\begin{array}{c}1983-2017 \\
1980-2017\end{array}$ \\
\hline
\end{tabular}




\subsection{Statistical Analysis}

The PAI, a water quality index developed for the South African eco-classification determination process, was applied to determine the present water quality status of the study area. The PAI is a tool used to determine the state of the physical and chemical water quality for a resource unit or a specific site. The PAI makes use of a Microsoft Excel-based weighting, ranking and rating framework that allows for the assessment of individual variables, the integration of the variable outcomes and then of the integrated overall water quality state [51]. This is based on a multi-criteria decision analysis that considers a range of water quality variables. These include $\mathrm{pH}$, salts, temperature $\left({ }^{\circ} \mathrm{C}\right)$, turbidity/clarity, dissolved oxygen $\left(\mathrm{mg} \mathrm{L}^{-1}\right)$ and various toxicants [52]. Ranking (1-4) and weighting $(0-100 \%)$ relates to the state of water quality under natural conditions. The importance of each of the variables (where 1 is least and 4 most important) is determined by whether the river is perennial or not, average width of the river and geomorphic zone [53]. The PAI compares each water quality variable to reference conditions in order to determine the degree to which each variable has changed, and this is rated from $0-5$ (where 0 is no change and 5 is extreme change) based on the degree with which water quality variables have changed from the reference conditions as well as the importance of each variable in relation to the possible biotic responses it may cause. The result is that each site is assigned an ecological category, ranging from $A$ to $F$ and a score ranging from 0 to 100 (Table 2) [52]. Weighting and ranking of the physicochemical variables for the Phongolo River was based on characteristics that are important for lowland rivers [53]. In lowland rivers, the order of metrics from most to least important are toxicants, nutrients, dissolved oxygen, temperature, $\mathrm{pH}$, salts and water clarity [53]. This analysis was applied to determine the PAI of each of the three sample sites (Upstream, Downstream 1 and Downstream 2 respectively). In order to determine the possible changes in water quality, first a historic PAI was calculated to assess the initial state of the river. Data from 1972 to 1976 from upstream of the impoundment were used to calculate the historic Upstream and Downstream 1 PAI. Recordings for Downstream 1 only started in 1984 and it is likely that water quality had already changed after the drought of 1983 and cyclone of 1984. However, even though the Pongolapoort Dam had been completed by 1973, flow was not yet regulated during this period and water flowed through unrestricted [78]. Water quality immediately below the impoundment would therefore have been similar to upstream of the impoundment. The historic water quality of Upstream were therefore used as a proxy for historic conditions at Downstream 1. Data from 1980 to 1982 were used to calculate the historic Downstream 2 PAI. More years could not be included due to the drought of 1983 and cyclone of 1984. Then, using data from 2009 to 2014, a PAI of pre-drought conditions was calculated to determine the water quality before the recent severe drought of 2015-2017. Using data from 2015 to 2017, a final PAI was calculated to determine whether water quality had changed during the severe supra-seasonal drought.

A time series assessment of the chemical water quality of the Phongolo River was performed. The water quality data obtained from the DWS database comprised of recordings taken once a month between 1972 and 2017, although data were not available for every month. Available data for each variable were averaged to annual records to determine trends in water quality at all sites from 1972 to 2017. Line graphs of the mean $( \pm S D)$ of each variable were created to visually assess the general trends and possible changes in water quality from 1972 to 2017 of all three data sets (Upstream, Downstream 1 and Downstream 2). In order to assess the possible influence of flow on the various water quality variables downstream of the dam (Downstream 1), regression analysis was performed on data from 1983 to 2017 as these were the only years that flow data were available for. Since autocorrelation (serial correlation) is a common occurrence in time-series data $[79,80]$, each dataset was tested for autocorrelation prior to regression analysis using the Durbin-Watson test. Linear regressions were then performed on those variables that were not autocorrelated and generalised least squares (gls) analysis applied on those that were autocorrelated. The Shapiro-Wilk test for normality was utilized to test whether data had a parametric distribution. The data distribution was not parametric and the Kruskal-Wallis $\mathrm{H}$ test for nonparametric data was therefore used to assess potential significant 
differences in water quality variables from 1972 to 2017 at each site and between the three sites. The Kruskal-Wallis $\mathrm{H}$ test was also used to assess water quality variables between the three categories created for PAI (historic, pre-drought and drought). Dunn's post-hoc test was then used to determine specific significant pairwise differences. To control for inflated false discovery rates, a Bonferroni correction was used.

To determine the potential effects of the Pongolapoort Dam, the upstream dataset (Upstream) was compared with the dataset immediately downstream of the dam (Downstream 1) using Principal Component Analysis (PCA) created in Canoco v5. Then, to compare whether water quality differed between the river outside and within NGR, a second PCA was created to compare the downstream water quality data outside NGR (Downstream 1) with the water quality data within NGR (Downstream 2). Each dataset was tested for multicollinearity using the variance inflation factor (vif) collinearity diagnostic test prior to PCA analysis. If the "vif" is $>10$, severe multicollinearity is present and variables causing this need to be excluded from multivariate analyses [81]. Variables with severe multicollinearity were excluded from further analysis. All water quality variables, with the exception of $\mathrm{pH}$, were then standardized by way of $\log$ transformation $[y=\log (x+1)]$ in order to reduce the distribution of skewness [82,83]. The gls analysis was performed in the "nlme" package in $\mathrm{R}$ (reference) while all other abovementioned tests were performed in IBM SPSS Statistics 23 (IBM Corp. Released 2015. IBM SPSS Statistics for Windows, Version 23.0., Armonk, NY, USA: IBM Corp.).

Due to multicollinearity, $\mathrm{Na}, \mathrm{Mg}^{+}$and conductivity were excluded from the Upstream dataset, $\mathrm{Na}$ and conductivity were excluded from the Downstream 1 dataset and $\mathrm{Cl}_{-}$, was excluded from the Downstream 2 datasets for PCA analysis. Principle component analysis has similarly been utilized in other manuscripts assessing temporal and seasonal changes in water quality of rivers (e.g., [84-86]). A PCA is based on a linear response model which relates a single variable (e.g., water data) to a particular site (or survey). A diagram of the assessed sites is visualized on a two-dimensional basis. Placement of the sites on the diagram signifies either similarities or dissimilarities between the measured variable and sites based on the angle of the variables to one another. Variables at $\leq 90^{\circ}$ are positively correlated while variables $>90^{\circ}$ are negatively correlated [87].

Table 2. Rating and ecological categories used for implementation of the Physicochemical Driver Assessment Index (PAI) scores [88].

\begin{tabular}{|c|c|c|}
\hline Ecological Category & Description & Score (Percentage of Total) \\
\hline A & Unmodified, natural. & 90-100 \\
\hline B & $\begin{array}{l}\text { Largely natural with few modifications. A small change in } \\
\text { natural habitats and biota may have taken place, but the } \\
\text { ecosystem functions are essentially unchanged. }\end{array}$ & $80-89$ \\
\hline $\mathrm{C}$ & $\begin{array}{l}\text { Moderately modified. Loss and change of natural habitat and } \\
\text { biota have occurred, but the basic ecosystem functions are still } \\
\text { predominantly unchanged. }\end{array}$ & $60-79$ \\
\hline D & $\begin{array}{l}\text { Largely modified. A large loss of natural habitat, biota and } \\
\text { basic ecosystem functions has occurred. }\end{array}$ & $40-59$ \\
\hline $\mathbf{E}$ & $\begin{array}{l}\text { Seriously modified. Extensive loss of natural habitat, biota } \\
\text { and basic ecosystem functions. }\end{array}$ & $20-39$ \\
\hline $\mathbf{F}$ & $\begin{array}{l}\text { Critically/Extremely modified. Modifications have reached a } \\
\text { critical level and the system has been modified completely, } \\
\text { with an almost complete loss of natural habitat and biota. In } \\
\text { the worst instances the basic ecosystem functions have been } \\
\text { destroyed and the changes are irreversible. }\end{array}$ & 0-19 \\
\hline
\end{tabular}

\section{Results}

The data are reported as an annual average per year for each site. Historical data sets obtained from the DWS monitoring stations comprised incomplete monthly records as they were not collected consistently for the same months of each year at each site. The data were thus highly variable, making direct comparisons between sites difficult. To make the data more comparable they were aggregated 
to represent annual records. The historic water quality of the middle and lower Phongolo River was in an unmodified, natural state (A rating) both above and below the Pongolapoort Dam (Figure 3; Table S4). The PAI\% indicated that Downstream 2 was in the most unmodified state (96.56\%) while Upstream and Downstream 1 had a lower score (88.39\%). From 2009 to 2014 (pre-drought) the river ecological category of all three sites declined to a moderately modified state ( $\mathrm{C}$ rating) and a PAI\% of $76.24 \%$. This was driven by an increase in all assessed variables at all three sites, with the exception of nutrients upstream of the dam which decreased (see Table 3). The river ecological category of all three sites remained in a moderately modified state during the drought (2015-2017) (Tables 3-5). However, there was a further decline in the PAI\% of Upstream and Downstream 2 and this was driven by an increase in $\mathrm{pH}$ and salts at the Upstream site and an increase in salts and nutrients at Downstream 2 (see Tables 3 and 5). During the drought, Downstream 2 was in the most modified state of the three sites (70.43\%) followed by Upstream (71.51\%) while Downstream 1 was the least modified (76.24\%).

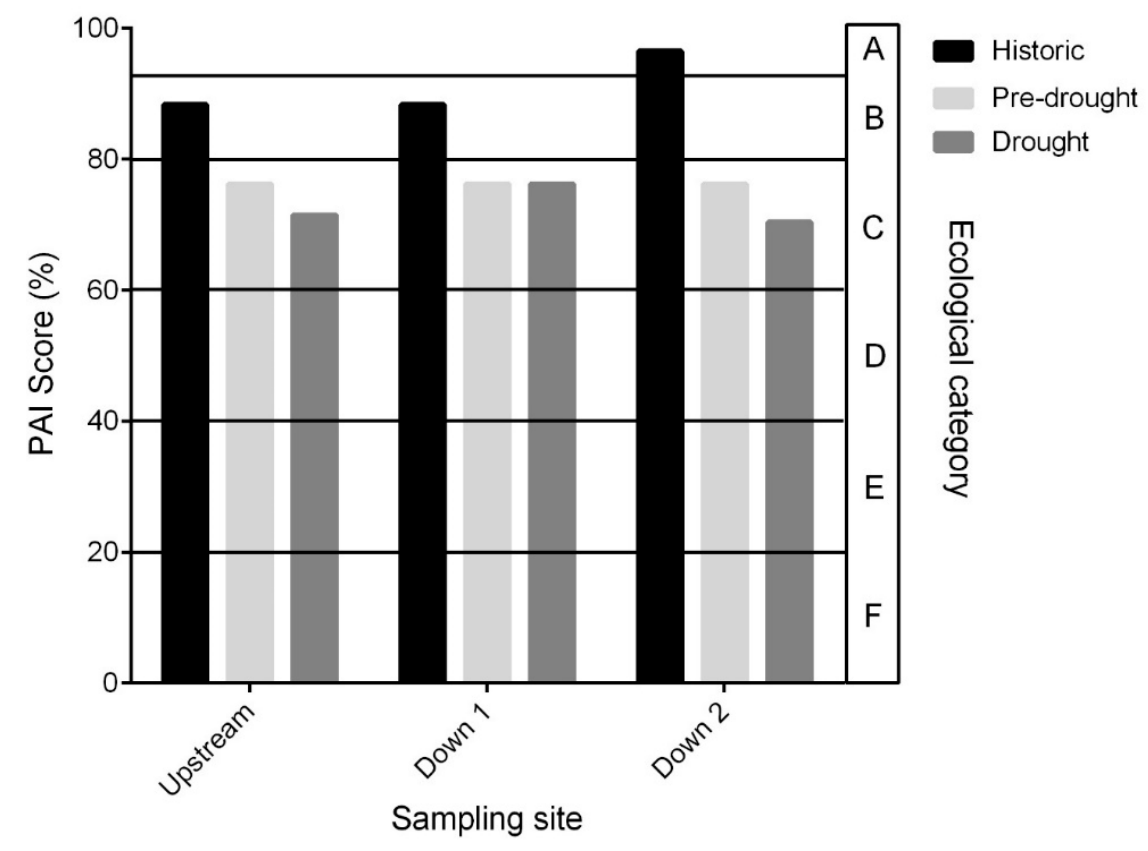

Figure 3. Physicochemical Driver Assessment Index (PAI) scores with associated river ecological category derived from the three monitoring stations located above and below Pongolapoort Dam. Upstream-Monitoring station located above the dam; Downstream 1 (Down 1)-Monitoring station located below dam wall. Downstream 2 (Down 2)-Monitoring station located within Ndumo Game Reserve.

Linear and generalised least squares regression analyses were used to predict changes in water quality variables based on changes in flow downstream of the Pongolapoort Dam (Table S5). The annual flow was found to have a significant effect on only two variables downstream of the Pongolapoort Dam, as the analyses revealed a significant linear effect of flow on $\mathrm{pH}\left(p=0.0006 ; \mathrm{F}_{1,366}=7.66\right)$ and $\mathrm{Mg}^{+},\left(p<0.001 ; \mathrm{F}_{1,366}=14.43\right)$ at Downstream 1 .

Several fluctuations were evident in the water quality variables both upstream and downstream of the Pongolapoort Dam during all sampling years (Figures 4-6). Kruskal-Wallis H tests revealed significant changes in these variables at all monitoring stations. An abrupt, significant increase in pH occurred between 1988 and 1991 where pH increased from approximately 7.5 between 1972 and 1988 to above 8 from 1991 onwards at all monitoring stations. Salinity (including conductivity, $\mathrm{Cl}^{-}$, $\mathrm{Ca}, \mathrm{Mg}+, \mathrm{K}$ and $\mathrm{Na}$ ), $\mathrm{NO}_{3}{ }^{-} / \mathrm{NO}_{2}{ }^{-}$and $\mathrm{PO}_{4}{ }^{3-}$ significantly increased during the severe droughts of 1983 to 1984,1991 to 1993 and 2015 to 2017 at all sites $(p<0.05)$. During these periods, conductivity ranged from $500 \mu \mathrm{S} \mathrm{cm} \mathrm{cm}^{-1}$ to above $1000 \mu \mathrm{S} \mathrm{cm}$ ch $^{-1}$ while decreasing to below $500 \mu \mathrm{S} \mathrm{cm}^{-1}$ in other years. Upstream of the Pongolapoort Dam, nutrients $\left(\mathrm{NO}_{3}{ }^{-} / \mathrm{NO}_{2}{ }^{-}, \mathrm{NH}_{4}{ }^{+}\right.$and $\left.\mathrm{PO}_{4}{ }^{3-}\right)$ fluctuated between 
years as well, particularly $\mathrm{NO}_{3}{ }^{-} / \mathrm{NO}_{2}{ }^{-}$. This variable increased significantly from $0.18 \mathrm{mg} \mathrm{L}^{-1}$ in 1972 to above $1 \mathrm{mg} \mathrm{L}^{-1}$ in 1984 and 1989 to 1995 and decreased significantly to approximately $0.45 \mathrm{mg} \mathrm{L}^{-1}$ in 1985 to 1989 and $0.7 \mathrm{mg} \mathrm{L}^{-1}$ in 1996 to 2017. Post-hoc analyses further revealed significant increases in conductivity $(p=0.046), \mathrm{pH}(p<0.0001), \mathrm{Mg}^{+}(p=0.003), \mathrm{Ca}(p=0.002), \mathrm{SO}_{4}{ }^{2-}(p<0.0001)$ and $\mathrm{K}$ $(p<0.0001)$ and significant decreases in $\mathrm{NO}_{3}{ }^{-} / \mathrm{NO}_{2}{ }^{-}(p<0.0001)$ and $\mathrm{NH}_{4}{ }^{+}(p<0.0001)$ from historic to pre-drought conditions (Table S6). From pre-drought to drought conditions post-hoc analysis indicated significant increases in conductivity $(p=0.002), \mathrm{pH}(p=0.049), \mathrm{Na}(p=0.003), \mathrm{Mg}^{+}(p=0.005), \mathrm{Cl}^{-}$ $(p=0.0008), \mathrm{SO}_{4}{ }^{2-}(p=0.02)$ and $\mathrm{NH}_{4}{ }^{+}(p<0.0001)$. Nutrients decreased significantly from 1984 to 2017 immediately below the impoundment (Downstream 1) $(p<0.05)$, as $\mathrm{NO}_{3}{ }^{-} / \mathrm{NO}_{2}{ }^{-}$decreased from $0.3 \mathrm{mg} \mathrm{L}^{-1}$ in 1984 to $<0.05 \mathrm{mg} \mathrm{L}^{-1}$ in 2010 and increasing again to $0.7 \mathrm{mg} \mathrm{L}^{-1}$ during the peak of the recent drought in 2016. Salinity increased significantly in 1985 to 1992, 2003 to 2008 and 2016 while decreasing from 1993 to 2002, 2009 to 2015 and 2017. Post-hoc analyses revealed significant increases in $\mathrm{pH}(p<0.0001)$ while significant decreases occurred in $\mathrm{Ca}(p<0.0001), \mathrm{Cl}^{-}(p<0.0001), \mathrm{NO}_{3}{ }^{-} / \mathrm{NO}_{2}{ }^{-}$ $(p<0.0001)$ and $\mathrm{NH}_{4}{ }^{+}(p=0.0001)$ from historic to pre-drought conditions (Table S7). Post-hoc analysis indicated significant changes in water quality from pre-drought to drought conditions with significant increases in conductivity $(p=0.02), \mathrm{Na}(p<0.0001), \mathrm{Mg}^{+}(p<0.0001), \mathrm{Ca}(p=0.002), \mathrm{Cl}^{-}(p<0.0001)$, $\mathrm{SO}_{4}{ }^{2-}(p=0.0004), \mathrm{PO}_{4}{ }^{3-}(p=0.01), \mathrm{K}(p=0.02)$ and $\mathrm{NH}_{4}{ }^{+}(p=0.003)$. Further downstream of the impoundment (Downstream 2), nutrients increased significantly from 1980 to 2017 as $\mathrm{NO}_{3}{ }^{-} / \mathrm{NO}_{2}{ }^{-}$ increased from $0.12 \mathrm{mg} \mathrm{L}^{-1}$ to $0.67 \mathrm{mg} \mathrm{L}^{-1}$ and $\mathrm{PO}_{4}{ }^{3-}$ from $0.006 \mathrm{mg} \mathrm{L}^{-1}$ to $0.02 \mathrm{mg} \mathrm{L}^{-1}$. Few significant changes were evident at Downstream 2 from the historic to pre-drought period (Table 5). Post-hoc analysis indicated a significant increase only in $\mathrm{pH}(p<0.0001)$ and a significant decrease in $\mathrm{NH}_{4}{ }^{+}$ $(p=0.04)$ while no significant changes occurred in water quality from the pre-drought to drought period (Table S8).

Table 3. Non-parametric Kruskal-Wallis H test results comparing historic, pre-drought (2009-2014) and drought (2015-2017) chemical water nutrient variables measured at the Department of Water and Sanitation (DWS) monitoring station located upstream of the Pongolapoort Dam (Upstream). Mean $\pm \mathrm{SD}$; range in parentheses.

\begin{tabular}{|c|c|c|c|c|}
\hline Variable & Historic & Pre-Drought & Drought & Significance \\
\hline Conductivity $\left(\mu S \mathrm{~cm}^{-1}\right)$ & $\begin{array}{l}503.6 \pm 343.5^{a} \\
(91-1840)\end{array}$ & $\begin{array}{c}422.3 \pm 170.2^{b} \\
(186.2-830)\end{array}$ & $\begin{array}{c}654.1 \pm 234.3^{a b} \\
(253-1074)\end{array}$ & $p<0.001 ; x^{2}=13.17$ \\
\hline $\mathrm{pH}$ & $\begin{array}{c}7.83 \pm 0.58 \mathrm{ab} \\
(6.08-8.97)\end{array}$ & $\begin{array}{c}8.35 \pm 0.21^{\mathrm{a}} \\
(7.23-8.71)\end{array}$ & $\begin{array}{c}8.55 \pm 0.33^{\mathrm{b}} \\
(7.7-8.91)\end{array}$ & $p<0.0001 ; \chi^{2}=54.12$ \\
\hline $\mathrm{Na}\left(\mathrm{mg} \mathrm{L}^{-1}\right)$ & $\begin{array}{c}63.98 \pm 49.80^{\mathrm{a}} \\
(8.1-227)\end{array}$ & $\begin{array}{c}48.02 \pm 22.78^{b} \\
(16.1-91.55)\end{array}$ & $\begin{array}{c}88.19 \pm 40.89 a b \\
(27-163.4)\end{array}$ & $p<0.003 ; \chi^{2}=11.35$ \\
\hline $\mathrm{Mg}^{+}\left(\mathrm{mg} \mathrm{L}^{-1}\right)$ & $\begin{array}{c}18.60 \pm 15.97^{\mathrm{a}} \\
(2.8-88.10)\end{array}$ & $\begin{array}{c}16.84 \pm 7.46^{b} \\
(6.28-30.23)\end{array}$ & $\begin{array}{c}26.38 \pm 9.79 \mathrm{ab} \\
(9.9-43)\end{array}$ & $p<0.0002 ; \chi^{2}=17.51$ \\
\hline $\mathrm{Ca}\left(\mathrm{mg} \mathrm{L}^{-1}\right)$ & $\begin{array}{c}16.86 \pm 9.92^{\mathrm{a}} \\
(2.9-60.9)\end{array}$ & $\begin{array}{l}17.21 \pm 5.93 \\
(7.11-31.98)\end{array}$ & $\begin{array}{c}20.72 \pm 5.97^{\mathrm{a}} \\
\quad(8.6-31.9)\end{array}$ & $p<0.0022 ; \chi^{2}=12.22$ \\
\hline $\mathrm{Cl}^{-}\left(\mathrm{mg} \mathrm{L}^{-1}\right)$ & $\begin{array}{l}47.01 \pm 34.53^{a} \\
\quad(5-203.6)\end{array}$ & $\begin{array}{c}29.24 \pm 12.39 \mathrm{ab} \\
(10.11-58.41)\end{array}$ & $\begin{array}{c}45.93 \pm 17.47^{b} \\
(15.6-75.2)\end{array}$ & $p=0.0016 ; \chi^{2}=12.82$ \\
\hline $\mathrm{NO}^{-} / \mathrm{NO}_{2}^{-}\left(\mathrm{mg} \mathrm{L}^{-1}\right)$ & $\begin{array}{c}0.55 \pm 0.61 \\
(0-3.1)\end{array}$ & $\begin{array}{l}0.48 \pm 0.24 \\
(0.03-1.04)\end{array}$ & $\begin{array}{l}0.45 \pm 0.33 \\
(0.05-1.17)\end{array}$ & $p=0.5264 ; \chi^{2}=1.28$ \\
\hline $\mathrm{SO}_{4}^{2-}\left(\mathrm{mg} \mathrm{L}^{-1}\right)$ & $\begin{array}{c}13.04 \pm 11^{a b} \\
(0-104.6)\end{array}$ & $\begin{array}{c}16.19 \pm 5.31^{\text {ac }} \\
(7.27-30.25)\end{array}$ & $\begin{array}{c}24.82 \pm 8.09 \text { bc } \\
(12.6-41.2)\end{array}$ & $p<0.0001 ; \chi^{2}=42.81$ \\
\hline $\mathrm{PO}_{4}{ }^{3-}\left(\mathrm{mg} \mathrm{L}^{-1}\right)$ & $\begin{array}{c}0.02 \pm 0.04 \\
(0-0.37)\end{array}$ & $\begin{array}{l}0.02 \pm 0.03 \\
(0.01-0.18)\end{array}$ & $\begin{array}{l}0.03 \pm 0.04 \\
(0.01-0.17)\end{array}$ & $p=0.2146 ; \chi^{2}=3.08$ \\
\hline$K\left(m g L^{-1}\right)$ & $\begin{array}{c}1.25 \pm 0.62 \mathrm{ab} \\
(0.22-4.89)\end{array}$ & $\begin{array}{c}2.4 \pm 0.55^{\mathrm{a}} \\
(1-3.27)\end{array}$ & $\begin{array}{c}2.4 \pm 1.15^{b} \\
(0.5-5.4)\end{array}$ & $p<0.0001 ; \chi^{2}=68.32$ \\
\hline $\mathrm{NH}_{4}{ }^{+}\left(\mathrm{mg} \mathrm{L}^{-1}\right)$ & $\begin{array}{c}0.07 \pm 0.12^{\mathrm{a}} \\
(0-1)\end{array}$ & $\begin{array}{c}0.03 \pm 0.01^{b} \\
(0.03-0.06)\end{array}$ & $\begin{array}{c}0.05 \pm 0 a^{a b} \\
(0.05-0.05)\end{array}$ & $p<0.0001 ; \chi^{2}=22.32$ \\
\hline
\end{tabular}

Common superscripts within rows indicate significant differences $(p<0.05)$. See Supplementary Table S6 for exact $p$-values. 
Table 4. Non-parametric Kruskal-Wallis H test results comparing historic, pre-drought (2009-2014) and drought (2015-2017) chemical water nutrient variables measured at the Department of Water and Sanitation (DWS) monitoring station located below the Pongolapoort Dam wall (Downstream 1). Mean $\pm \mathrm{SD}$; range in parentheses.

\begin{tabular}{|c|c|c|c|c|}
\hline Variable & Historic & Pre-Drought & Drought & Significance \\
\hline Conductivity $\left(\mu S \mathrm{~cm}^{-1}\right)$ & $\begin{array}{c}503.6 \pm 343.5^{a b} \\
(91-1840)\end{array}$ & $\begin{array}{c}286.4 \pm 21.22^{\mathrm{a}} \\
(254.4-353.5)\end{array}$ & $\begin{array}{c}336.4 \pm 51.11^{b} \\
(281.4-504)\end{array}$ & $p<0.0001 ; \chi^{2}=22.83$ \\
\hline $\mathrm{pH}$ & $\begin{array}{c}7.83 \pm 0.58^{a b} \\
(6.08-8.97)\end{array}$ & $\begin{array}{l}8.3 \pm 0.16^{\mathrm{a}} \\
(7.71-8.51)\end{array}$ & $\begin{array}{c}8.36 \pm 0.15^{b} \\
(8-8.6)\end{array}$ & $p<0.0001 ; \chi^{2}=36.02$ \\
\hline $\mathrm{Na}\left(\mathrm{mg} \mathrm{L}^{-1}\right)$ & $\begin{array}{c}63.98 \pm 49.80^{a} \\
(8.1-227)\end{array}$ & $\begin{array}{l}29.85 \pm 2.88^{b} \\
(25.98-34.48)\end{array}$ & $\begin{array}{c}37.62 \pm 8.08^{a b} \\
(27.26-62.5)\end{array}$ & $p<0.0001 ; \chi^{2}=38.68$ \\
\hline $\mathrm{Mg}^{+}\left(\mathrm{mg} \mathrm{L}^{-1}\right)$ & $\begin{array}{c}18.60 \pm 15.97^{\mathrm{a}} \\
(2.8-88.10)\end{array}$ & $\begin{array}{l}10.2 \pm 1.64^{a} \\
(8.25-16.78)\end{array}$ & $\begin{array}{c}12.32 \pm 2.27 \\
(9.62-20)\end{array}$ & $p<0.0003 ; \chi^{2}=16.29$ \\
\hline $\mathrm{Ca}\left(\mathrm{mg} \mathrm{L}^{-1}\right)$ & $\begin{array}{c}16.86 \pm 9.92^{\mathrm{a}} \\
(2.9-60.9)\end{array}$ & $\begin{array}{c}12.82 \pm 1.04^{\mathrm{a}} \\
(9.92-15.12)\end{array}$ & $\begin{array}{c}15.9 \pm 3.44 \\
(10.8-23)\end{array}$ & $p<0.016 \chi^{2}=8.27$ \\
\hline $\mathrm{Cl}^{-}\left(\mathrm{mg} \mathrm{L}^{-1}\right)$ & $\begin{array}{c}47.01 \pm 34.53^{\mathrm{a}} \\
\quad(5-203.6)\end{array}$ & $\begin{array}{c}20.28 \pm 2.15^{\mathrm{a}} \\
(17.28-)\end{array}$ & $\begin{array}{l}29 \pm 10.14^{b} \\
(19.65-63.4)\end{array}$ & $p<0.0001 ; \chi^{2}=33.12$ \\
\hline $\mathrm{NO}^{-} / \mathrm{NO}_{2}^{-}\left(\mathrm{mg} \mathrm{L}^{-1}\right)$ & $\begin{array}{c}0.55 \pm 0.61^{\mathrm{a}} \\
(0-3.1)\end{array}$ & $\begin{array}{l}0.22 \pm 0.4^{\mathrm{a}} \\
(0.005-2.02)\end{array}$ & $\begin{array}{c}0.33 \pm 0.72 \\
(0.05-3.6)\end{array}$ & $p<0.007 ; \chi^{2}=9.92$ \\
\hline $\mathrm{SO}_{4}{ }^{2-}\left(\mathrm{mg} \mathrm{L}^{-1}\right)$ & $\begin{array}{c}13.04 \pm 11^{a} \\
(0-104.6)\end{array}$ & $\begin{array}{c}11.37 \pm 1.17^{\mathrm{b}} \\
(9.25-14.18)\end{array}$ & $\begin{array}{c}14.83 \pm 3.49^{a b} \\
(7.93-23.2)\end{array}$ & $p<0.005 ; \chi^{2}=10.64$ \\
\hline $\mathrm{PO}_{4}{ }^{3-}\left(\mathrm{mg} \mathrm{L}^{-1}\right)$ & $\begin{array}{c}0.02 \pm 0.04 \\
(0-0.37)\end{array}$ & $\begin{array}{c}0.009 \pm 0.008 \\
(0.005-0.05)\end{array}$ & $\begin{array}{c}0.01 \pm 0.003 \\
(0.01-0.05)\end{array}$ & $p=0.1410 ; \chi^{2}=3.92$ \\
\hline$K\left(m g L^{-1}\right)$ & $\begin{array}{c}1.25 \pm 0.62^{\mathrm{a}} \\
(0.22-4.89)\end{array}$ & $\begin{array}{c}2.69 \pm 0.57^{b} \\
(1-3.8)\end{array}$ & $\begin{array}{c}2.73 \pm 0.71 \mathrm{ab} \\
(1.13-4.49)\end{array}$ & $p<0.0001 ; \chi^{2}=38.98$ \\
\hline $\mathrm{NH}_{4}{ }^{+}\left(\mathrm{mg} \mathrm{L}^{-1}\right)$ & $\begin{array}{c}0.07 \pm 0.12^{\mathrm{a}} \\
(0-1)\end{array}$ & $\begin{array}{c}0.04 \pm 0.01^{b} \\
(0.03-0.07)\end{array}$ & $\begin{array}{l}0.05 \pm 0^{\mathrm{ab}} \\
(0.05-0.05)\end{array}$ & $p=0.0015 ; \chi^{2}=12.97$ \\
\hline
\end{tabular}

Common superscripts within rows indicate significant differences $(p<0.05)$. See Supplementary Table S7 for exact $p$-values.

Table 5. Non-parametric Kruskal-Wallis H test results comparing historic, pre-drought (2009-2014) and drought (2015-2017) chemical water nutrient variables measured at the Department of Water and Sanitation (DWS) monitoring station located within Ndumo Game Reserve (Downstream 2). Mean \pm SD; range in parentheses.

\begin{tabular}{|c|c|c|c|c|}
\hline Variable & Historic & Pre-Drought & Drought & Significance \\
\hline Conductivity $\left(\mu S \mathrm{~cm}^{-1}\right)$ & $\begin{array}{c}544.4 \pm 292.7 \\
(188-1166)\end{array}$ & $\begin{array}{c}482.5 \pm 97.26 \\
(306.9-647)\end{array}$ & $\begin{array}{c}422.3 \pm 199.2 \\
(176-679)\end{array}$ & $p=0.57 ; \chi^{2}=1.14$ \\
\hline $\mathrm{pH}$ & $\begin{array}{c}7.05 \pm 0.34^{\mathrm{a}} \\
(6.31-7.86)\end{array}$ & $\begin{array}{c}8.26 \pm 0.21^{a} \\
(7.64-8.59)\end{array}$ & $\begin{array}{c}8.13 \pm 0.33 \\
(7.5-8.56)\end{array}$ & $p<0.0001 ; \chi^{2}=75.41$ \\
\hline $\mathrm{Na}\left(\mathrm{mg} \mathrm{L}^{-1}\right)$ & $\begin{array}{l}63.3 \pm 35.52 \\
(19.8-140.8)\end{array}$ & $\begin{array}{c}56.98 \pm 11.5 \\
(35.15-73.45)\end{array}$ & $\begin{array}{c}39.05 \pm 25.98 \\
(17.2-80.15)\end{array}$ & $p=0.009 ; \chi^{2}=9.47$ \\
\hline $\mathrm{Mg}^{+}\left(\mathrm{mg} \mathrm{L}^{-1}\right)$ & $\begin{array}{c}17.13 \pm 9.62 \\
(6.7-38.1)\end{array}$ & $\begin{array}{c}16.88 \pm 7.31 \\
(10.28-46.34)\end{array}$ & $\begin{array}{c}15.27 \pm 6.31 \\
(5.6-26.21)\end{array}$ & $p=0.29 ; \chi^{2}=2.46$ \\
\hline $\mathrm{Ca}\left(\mathrm{mg} \mathrm{L}^{-1}\right)$ & $\begin{array}{c}22.09 \pm 10.36 \\
(7.9-45.4)\end{array}$ & $\begin{array}{l}18.88 \pm 6.26 \\
(12.02-48.7)\end{array}$ & $\begin{array}{c}15.42 \pm 5.85 \\
(6.3-20.7)\end{array}$ & $p=0.45 ; \chi^{2}=1.62$ \\
\hline $\mathrm{Cl}^{-}\left(\mathrm{mg} \mathrm{L}^{-1}\right)$ & $\begin{array}{c}80.49 \pm 65.07 \\
(14.5-214.5)\end{array}$ & $\begin{array}{c}56.42 \pm 18.4 \\
(28.44-104.3)\end{array}$ & $\begin{array}{c}50.18 \pm 31.92 \\
(14.4-95.43)\end{array}$ & $p=0.52 ; \chi^{2}=1.31$ \\
\hline $\mathrm{NO}^{-} / \mathrm{NO}_{2}^{-}\left(\mathrm{mg} \mathrm{L}^{-1}\right)$ & $\begin{array}{c}0.19 \pm 0.21 \\
(0-0.92)\end{array}$ & $\begin{array}{l}0.12 \pm 0.08 \\
(0.03-0.28)\end{array}$ & $\begin{array}{l}0.31 \pm 0.51 \\
(0.05-1.39)\end{array}$ & $p=0.46 ; \chi^{2}=1.57$ \\
\hline $\mathrm{SO}_{4}{ }^{2-}\left(\mathrm{mg} \mathrm{L}^{-1}\right)$ & $\begin{array}{c}18.27 \pm 16.69 \\
(4.7-96.8)\end{array}$ & $\begin{array}{l}20.35 \pm 14.52 \\
(10.24-102.2)\end{array}$ & $\begin{array}{c}12.48 \pm 5.55 \\
(6-21.31)\end{array}$ & $p=0.09 ; \chi^{2}=4.88$ \\
\hline $\mathrm{PO}_{4}{ }^{3-}\left(\mathrm{mg} \mathrm{L}^{-1}\right)$ & $\begin{array}{c}0.01 \pm 0.02 \\
(0-0.08)\end{array}$ & $\begin{array}{l}0.02 \pm 0.05 \\
(0.01-0.29)\end{array}$ & $\begin{array}{c}0.02 \pm 0.0 .02 \\
(0.01-0.05)\end{array}$ & $p=0.02 ; \chi^{2}=8.28$ \\
\hline$K\left(\mathrm{mg} \mathrm{L}^{-1}\right)$ & $\begin{array}{l}2.22 \pm 1.01 \\
(1.26-6.87)\end{array}$ & $\begin{array}{c}3.2 \pm 0.62 \\
(1-4.2)\end{array}$ & $\begin{array}{c}3.44 \pm 1.08 \\
(2.3-4.9)\end{array}$ & $p=0.52 ; \chi^{2}=1.31$ \\
\hline $\mathrm{NH}_{4}+\left(\mathrm{mg} \mathrm{L}^{-1}\right)$ & $\begin{array}{c}0.04 \pm 0.03^{a b} \\
(0-0.14)\end{array}$ & $\begin{array}{c}0.04 \pm 0.02^{\mathrm{a}} \\
(0.03-0.11)\end{array}$ & $\begin{array}{c}0.05 \pm 0^{b} \\
(0.05-0.05)\end{array}$ & $p=0.003 ; \chi^{2}=11.54$ \\
\hline
\end{tabular}

Common superscripts within rows indicate significant differences $(p<0.05)$. See Supplementary Table S8 for exact $p$-values. 
a

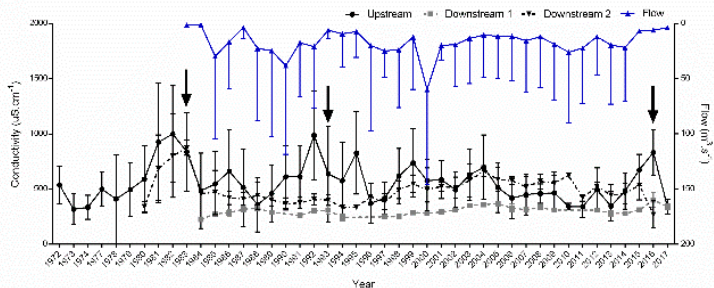

C

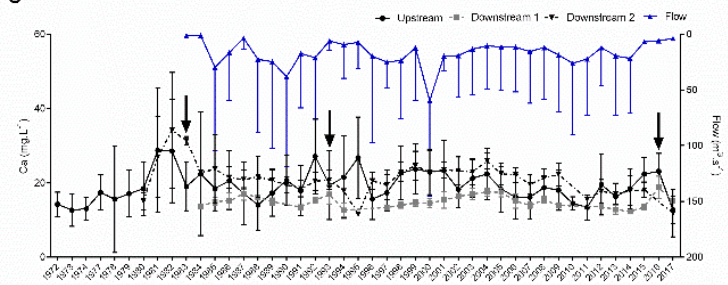

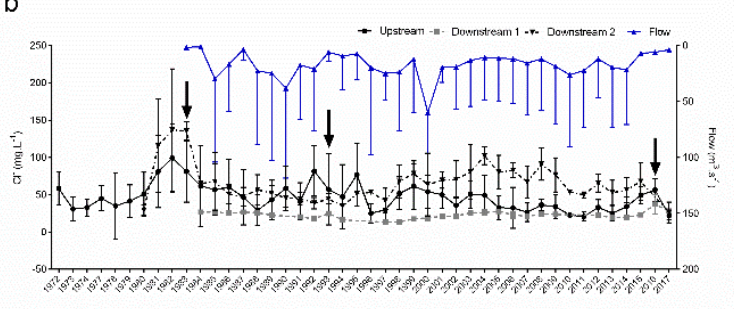

rear

d

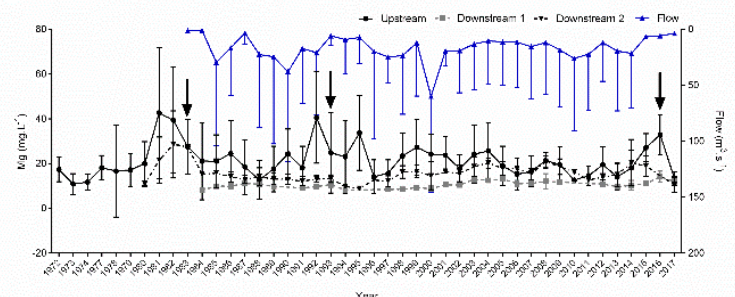

Figure 4. Line graphs indicating mean $( \pm \mathrm{SD})$ trends in conductivity (a), chlorides (b), calcium (c) and magnesium (d) measured from 1972 to 2017 at the Department of Water and Sanitation (DWS) monitoring stations located above and below the Pongolapoort Dam. Arrows indicate peak years of severe drought. Annual flow for each available year is indicated by the blue line. Upstream-Monitoring station located above the dam; Downstream 1-Monitoring station located below dam wall. Downstream 2-Monitoring station located within Ndumo Game Reserve. Significant differences between years and sites are indicated in the text.

a

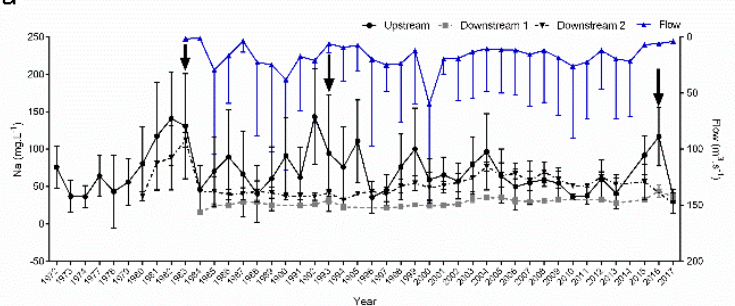

C

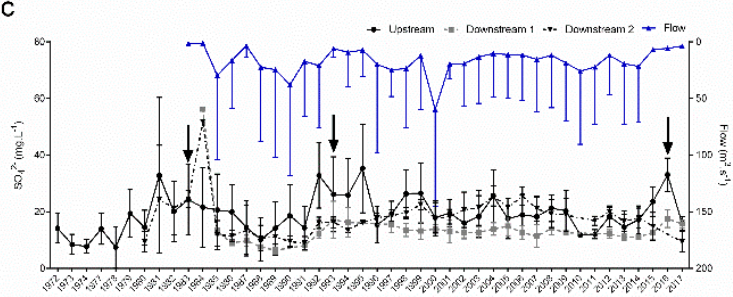

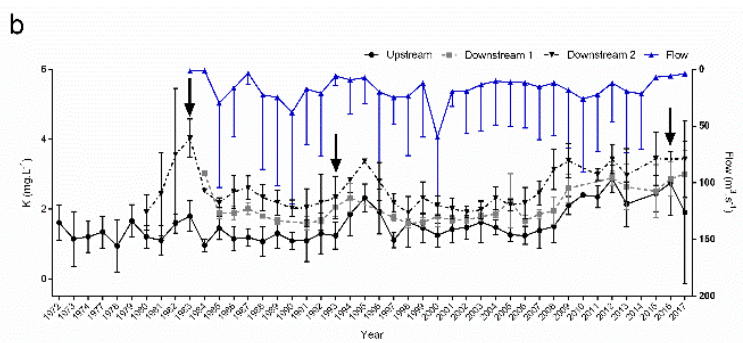

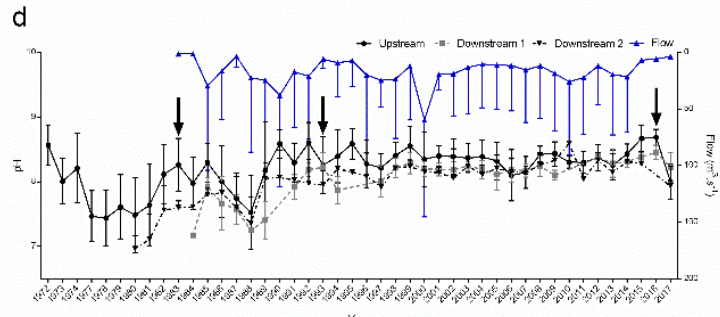

Figure 5. Line graphs indicating mean $( \pm \mathrm{SD})$ trends in sodium $(\mathbf{a})$, potassium $(\mathbf{b})$, sulphates $(\mathbf{c})$ and $\mathrm{pH}$ (d) measured from 1972 to 2017 at the Department of Water and Sanitation (DWS) monitoring stations located above and below the Pongolapoort Dam. Arrows indicate peak years of severe drought. Annual flow for each available year is indicated by blue line. Upstream-Monitoring station located above the dam; Downstream 1-Monitoring station located below dam wall. Downstream 2-Monitoring station located within Ndumo Game Reserve. Significant differences between years and sites are indicated in the text. 
a

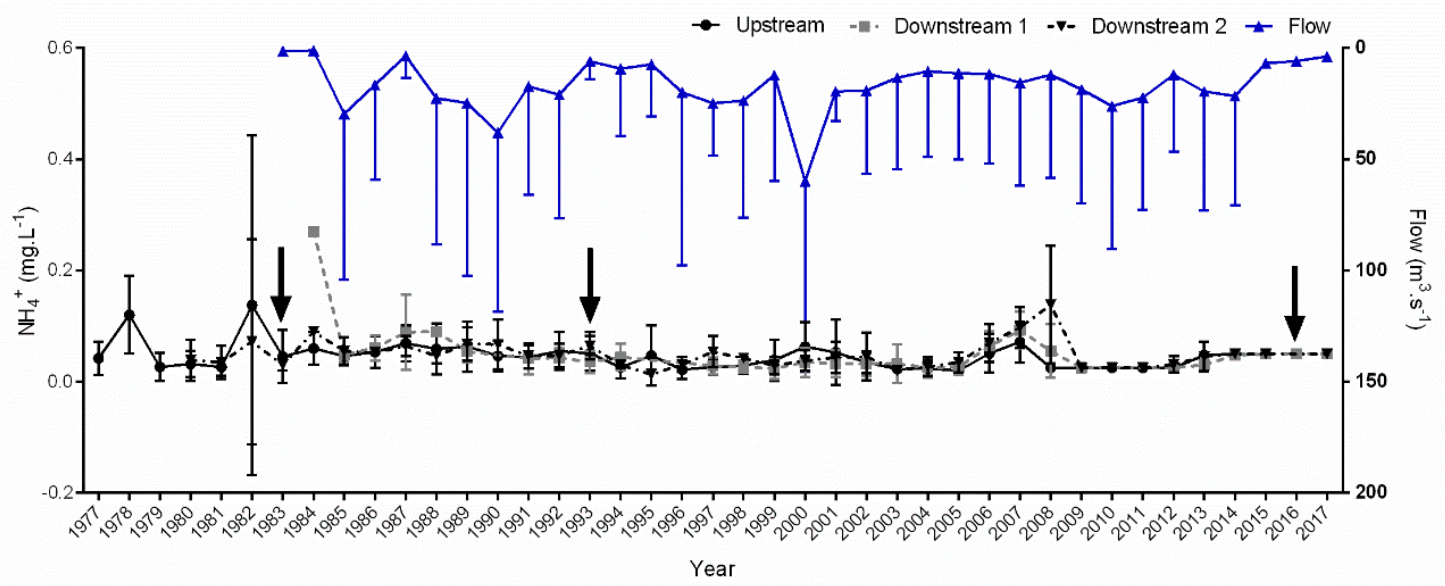

b

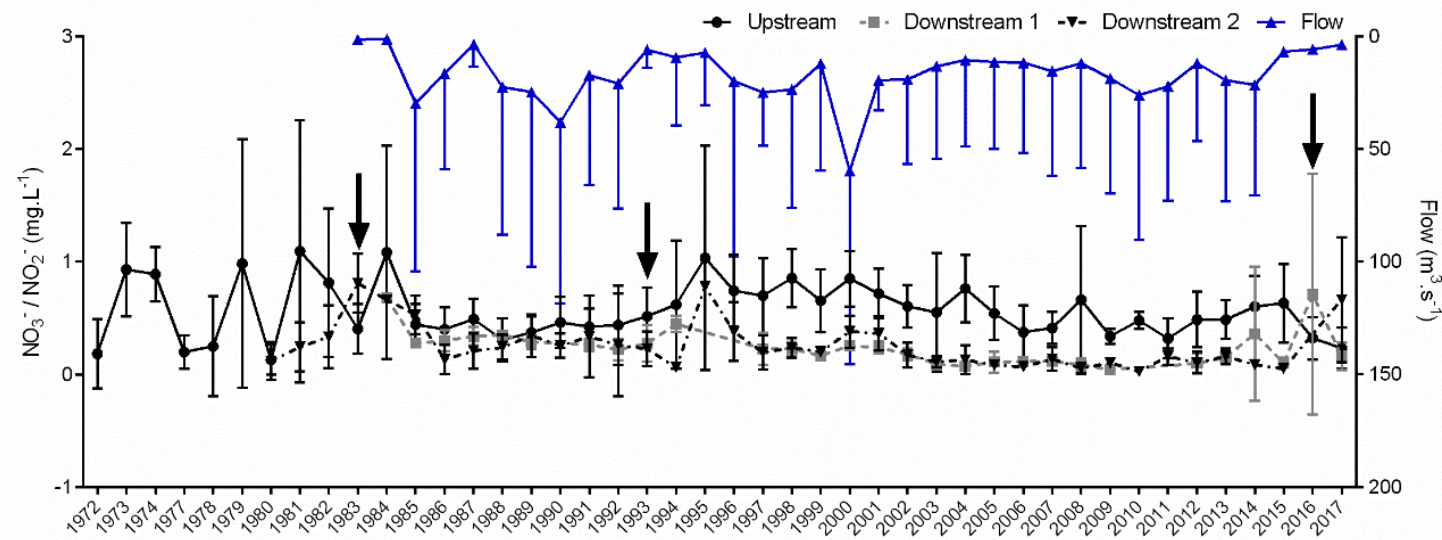

Year

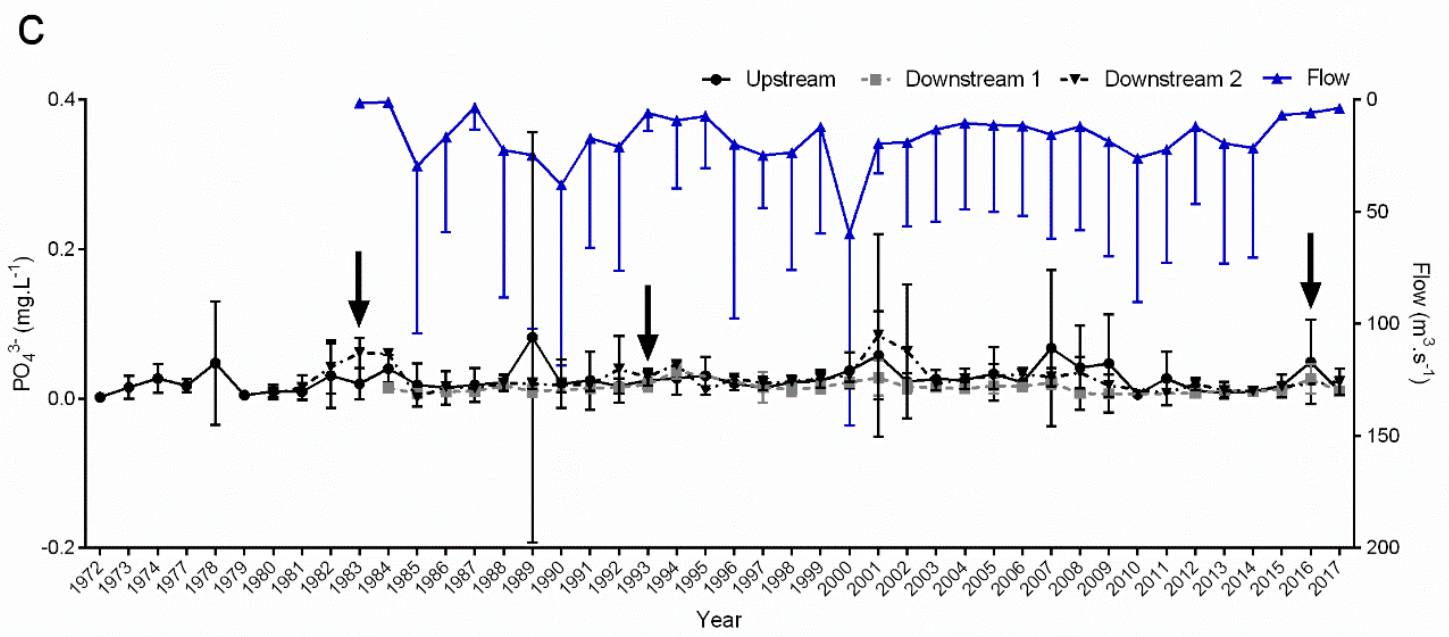

Figure 6. Line graphs indicating mean $( \pm \mathrm{SD})$ trends in ammonium (a), nitrates/nitrites $(\mathbf{b})$, and orthophosphates (c) measured from 1972 to 2017 at the Department of Water and Sanitation (DWS) monitoring stations located above and below the Pongolapoort Dam. Arrows indicate peak years of severe drought. Annual flow for each available year is indicated by blue line. Upstream-Monitoring station located above the dam; Downstream 1-Monitoring station located below dam wall. Downstream 2-Monitoring station located within Ndumo Game Reserve. Significant differences between years and sites are indicated in the text. 
Spatial separation was evident in the PCA comparing the Upstream and Downstream 1 sites between 1972 and 2017 (explaining a total of 57.34\% of data variation), as upstream survey years separated distinctly from downstream survey years along Axis 1 (explaining 39.19\% of data variation) (Figure S1). Post-hoc analysis revealed this to be driven largely by significantly lower salts (in the form of $\mathrm{Cl}^{-}, \mathrm{Ca}$ and $\mathrm{SO}_{4}{ }^{2-}$ ) and nutrients (in the form of $\mathrm{NO}_{3}{ }^{-} / \mathrm{NO}_{2}{ }^{-}$and $\mathrm{PO}_{4}{ }^{3-}$ ) immediately downstream of the Pongolapoort Dam compared to upstream of the dam from 1984 onwards $(p<0.05$; Tables S2 and S3). Separation along Axis 2 (explaining 18.15\% of data variation) was largely driven by higher values of $\mathrm{NH}_{4}{ }^{+}$in 1984 downstream of the dam compared to upstream. Separation along this axis was also driven by temporal variation in $\mathrm{pH}$ which increased significantly from the 1990s onwards at both sites. Spatial separation was also evident on the PCA comparing the two downstream sampling sites (Downstream 1 and 2) (explaining 58.08\% of data variation) (Figure S2). Survey years from Downstream 1 and 2 separated distinctly from one another along Axis 1 (explaining $34.07 \%$ of data variation) and post-hoc analysis indicated this was mainly driven by significantly higher $\mathrm{Ca}$, $\mathrm{SO}_{4}{ }^{2-}$ and $\mathrm{Cl}^{-}$at Downstream 2 compared to Downstream 1, particularly in 2010 and $2016(p<0.05)$. Separation along Axis 2 (explaining 24.01\% of data variation) was largely attributed to temporal variation in $\mathrm{pH}$ and $\mathrm{NH}_{4}{ }^{+}$. While $\mathrm{pH}$ was significantly lower in the 1980s and increased from the 1990s onwards at both downstream sites $(p<0.05), \mathrm{NH}_{4}{ }^{+}$was much higher in 1984 at Downstream 1 compared to any other sites.

\section{Discussion}

The aims of this study were to assess the historical water quality of the middle and lower Phongolo River, determine whether Pongolapoort Dam has had any effect on water quality of the lower Phongolo River and ascertain whether the most recent severe supra-seasonal drought experienced from 2015 to 2017 led to changes in water quality of the Phongolo River. The main findings of the study were that the quality of water in the middle and lower Phongolo River has decreased from historic to present condition, largely as a result of continued increases in salinity, both above and below the dam. A significant decrease in nutrients and salts immediately below the dam suggests the Pongolapoort Dam is trapping nutrient-rich sediments, although no severe long-term adverse effects on water quality were apparent below the impoundment. Conversely, water quality further downstream of the impoundment, within NGR, had degraded the most of the three studied sites. Finally, the recent drought (from 2015 to 2017) did not appear to affect water quality of the Phongolo River severely, as there was little change water quality from pre-drought to drought conditions.

The middle and lower Phongolo River has seen a decrease in its river ecological category and PAI\% from the 1970s to the present along with a steady increase in $\mathrm{pH}$ and salinity and changes in organic and inorganic nutrients. Nutrients have significantly decreased above the Pongolapoort Dam from historic to pre-drought conditions, particularly after 1995, while further below the impoundment, within NGR, nutrients have increased since the 1980s. Immediately below the Pongolapoort Dam, the river has historically been poorer in nutrients than either assessed site above the dam or within NGR. Since Pongolapoort Dam was completed, there has been an increase in the number of irrigation schemes and farms, as well as a substantial population growth both above and below the dam. An influx of various constituents through return flows from mines and agricultural activities surrounding the Phongolo River are the most likely sources for these significant changes in water chemistry of the Phongolo River. The upper and middle reaches of the Phongolo River have been subjected to a myriad of anthropogenic inputs since the 1960s [69] and this was reflected by an historically lower PAI\% than below the Pongolapoort Dam. These changes to the land surrounding the middle and lower reaches of the Phongolo River have resulted in an increased use of pesticides, organic and inorganic fertilizers $[58,62,65,66]$ as well as DDT use for malaria vector control, as the lower Phongolo River lies in a low-risk malaria region [57]. The upper reaches are exposed to both functioning and abandoned coal mines near Paulpietersburg, as well as by commercial forestry developments on both the Phongolo and Bivane rivers [62]. In the middle reaches, there are approximately $199 \mathrm{~km}^{2}$ of mostly sugarcane 
farms $[26,35,65]$, and water from the upper reaches is allocated for forestry, as well as for the Impala Irrigation Scheme in the middle Phongolo River reaches [65]. Nutrients entering the Pongolapoort Dam have also decreased since 1995 and this coincides with the completion of the Bivane Dam, along with reported reductions in water inflow into Pongolapoort Dam [66].

Although a $40 \%$ increase in the transformation of the lower Phongolo floodplain's natural vegetation into agricultural land occurred between 1955 and 2003 [89], the lower Phongolo River has only truly been utilized since the 1980s when the Makhathini Irrigation Scheme started in 1982. By 1988-1989, approximately 3500 ha of land of the lower Phongolo River was utilized for cotton production [90]. This included not only small subsistence farms, but also larger commercial cotton and sugarcane farms [54]. The population has also increased, from approximately 40,000 people living around the floodplain in 1982 [63] to approximately 198,000 people in 2016 [59]. Water from return flows and tailwaters from irrigation schemes and mining activities often contains high levels of total dissolved solids (TDS), including the dissolved cations calcium, magnesium, sodium and potassium, and anions such as sulphates, chlorides, fluoride, nitrate, bicarbonate and carbonate [91] and numerous other agro-pollutants leached from soils [35,92-95]. Merchán et al. [94] also determined that the main causes for increased salinity in the Lerna Basin in Spain were inputs from irrigation water. Similarly, research has found that increased water alkalinity and salinity in the Crocodile River catchment in South Africa was due to anthropogenic pollution, including inputs from agricultural and mining return flows $[35,83]$

The present study found the lower Pongolo River to have historically been poorer in nutrients just downstream of the dam than either above the dam or within NGR. Depending on the size, retention time and type of discharge, impoundments may either cause severe nutrient loads into the downstream river or retain sediment, silt and nutrients and thus decrease the passage of these constituents to the downstream river [13,92,96-98] Both the Bivane and Pongolapoort Dam have most likely reduced sediment passage, and thus nutrient flow into the rivers downstream of each of these impoundments. Since being built, the amount of sediment Pongolapoort Dam carries downstream has decreased [8] and this is most certainly the case of the Bivane Dam as well. Similar findings were reported by Heeg and Breen [99] and DWS [60] for the lower Phongolo River. In other regions, Zeng et al. [100] discerned a loss of major nutrients below the Xinhe Dam, China due to sediment trapping, and González et al. [101] found lower nutrient concentrations in the rivers downstream of four impoundments in central Spain than within the impoundments.

In 2014 the DWS reported that the water quality of the Phongolo River below the dam is in a good but deteriorating state $[60,65]$. This was corroborated by the present study that found the river below the Pongolapoort Dam to have deteriorated from a river ecological category of $\mathrm{A}$ to $\mathrm{C}$. This was driven by increases in not only salinity, but most markedly by increases in nutrients within the NGR, which has deteriorated the most amongst all three assessed sites, having the lowest final PAI\%. Lowland rivers such as the lower Phongolo River are characterized as regions with distinct floodplains and alluvial, fine-bed channels [102]. The soils of these rivers, particularly those in the wetlands associated with them, are highly fertile due to the fine sediments in the wetlands that are able to absorb a high concentration of nutrients [103] and are the reason why many farmers plant crops within floodplains. These habitats are therefore highly dependent on receiving nutrient-rich sediment during flooding to replenish the soils [103]. When a dam traps these sediments, as has occurred with Pongolapoort Dam, there is a loss of fertile soil deposits into the floodplain wetlands $[8,104]$. Therefore, along with the reduction of nutrients in the water of the lower Phongolo River, there has most likely also been a loss of nutrient rich soils in the floodplain wetlands associated with the lower Phongolo River. This loss of natural nutrients is often offset through the increased use of fertilizers on farms surrounding an aquatic ecosystem [105]. Farms in the lower Phongolo region not only abstract water from the river for irrigation, but also make use of nitrogen-rich fertilizers in order to maximize crop yields [57] and have thus led to an influx of nutrient rich run-off into the river flowing into NGR.

During the peak of the droughts in 1983, 1993 and 2016, the flow from the dam was severely reduced, with only a low continuous baseflow released as per cross-border agreements with Mozambique [60]. 
This low flow was accompanied by acute increases in water salinity and nutrients observed during the peaks of each of these droughts and the inverse relationship between flow and salts. As flow decreased, the various salts and $\mathrm{pH}$ increased, while the opposite was true with increases in flow. The present study also found these variables to increase further from 2016 to 2017. These changes in the water quality are most likely due to a combination of the natural geology of the region, increased agricultural activities and, in the case of the more recent drought, a further reduction in river flow from 2016 to 2017. Cretaceous marine sediments make up a great deal of the region's geology and produces naturally saline groundwater that seeps into the river $[8,106]$. The dissolved salts levels in the lower Phongolo are therefore naturally slightly higher than most other freshwater river systems, resulting in slightly more saline water within the lower Phongolo River, particularly where it flows into NGR. These dissolved salts levels are particularly high during periods of low flow [63], and the additional accumulation of ions, increased alkalinity and high salt concentrations occur during extended periods of drought [107]. Similar results were reported by Kelly et al. [96] where water flowing into the Rio Grande Basin (USA) was more saline during periods of drought due to increased inputs from saline ground water. Water quality diminished further during the 2016 drought, largely due to increased salinity and $\mathrm{pH}$. When there is regular flow for longer periods of time, and reduced extreme low-flow events, less flushing of the system occurs. This causes an accumulation of minerals and leaching of nutrient-rich water [8], which may reduce water quality and the health of the aquatic ecosystem in the long-term. However, the changes in water quality observed during the present study were not accompanied by a further decrease in river ecological category, which remained in a moderately modified state. The baseflow released from the dam was enough to sustain the present quality of water without severe further deterioration by continuously providing freshwater to the ecosystem and preventing stagnation of water. The reasons for acute increases in $\mathrm{Ca}, \mathrm{SO}_{4}{ }^{2-}, \mathrm{PO}_{4}{ }^{3-}$ at Downstream 2 in 2010 are unclear, as only one data point is available for this year at this monitoring station, making it difficult to draw definitive conclusions and will therefore not be discussed further.

\section{Conclusions}

This study aimed to assess long-term water quality trends of the Phongolo River above and below the Pongolapoort Dam, as well as ascertain whether the dam or the recent severe supra-seasonal drought had any recent effects on water quality of the Phongolo River. The suite of analyses used to assess the water quality and potential impacts during the past approximately five decades supported the first hypothesis, as results revealed that water quality has significantly changed and become much poorer since the 1970s to the present day. It was further found that the water of the middle Phongolo River had already been impacted historically before entering Pongolapoort Dam as it had the lowest historic PAI\% value of the three sites and supported the second hypothesis. The Pongolapoort Dam does appear to affect water quality by significantly decreasing salts and nutrients entering the lower Phongolo River. However, these changes have not led to severe negative impacts on water quality, as the final PAI\% was highest immediately below the dam compared to either upstream or further downstream of the dam and therefore did not support the third hypothesis. Finally, although significant changes occurred in water quality parameters from pre-drought to drought conditions during the supra-seasonal drought, this did not severely affect the Phongolo River's ecological status as it remained in a moderately modified state and the final hypothesis was therefore not supported.

This study was limited by the inconsistency of the availability of historical data, as monthly records obtained from the DWS monitoring stations consisted of incomplete recordings, making direct comparisons between data sets difficult. To make data more comparable, monthly data sets were therefore averaged to annual data. The results from this study still provide valuable insight into the long-term water quality trends and effect of long-term anthropogenic use of the lower Phongolo River, which is lacking for this ecologically important ecosystem. This study was able to successfully make use of multivariate statistical analyses and a water quality index in order to elucidate long-term trends and the present state of an important lowland river in Southern Africa. Taking long-term trends in 
water quality into consideration provides a clearer indication of the historic and present anthropogenic influences on an aquatic ecosystem. It also enables researchers and management authorities to focus on potential future threats that need to be addressed in order to prevent further ecological changes.

Supplementary Materials: The following are available online at http://www.mdpi.com/2073-4441/12/1/37/s1, Figure S1: Principal Component Analysis (PCA) biplot comparing water quality variables from 1972 to 2017 measured at the Department of Water and Sanitation (DWS) monitoring stations above (Upstream; red dots) and immediately below (Downstream 1; green squares) Pongolapoort Dam. The biplot explains 58.08\% of data variation, of which $34.07 \%$ is explained by the first axis and $24.01 \%$ is explained by the second axis; Figure S2: Principal Component Analysis (PCA) biplot comparing water quality variables from 1981 to 2017 measured at the Department of Water and Sanitation (DWS) monitoring stations immediately below the Pongolapoort Dam (Downstream 1; green dots) and within Ndumo Game Reserve (Downstream 2; red squares). The biplot explains $57.34 \%$ of data variation, of which $39.19 \%$ is explained by the first axis and $18.15 \%$ is explained by the second axis; Table S1: Water quality variable measurements and number of samples available for each year $(\mathrm{N})$ of the Phongolo River measured at the Department of Water and Sanitation (DWS) monitoring station located upstream of the Pongolapoort Dam (Upstream) from 1972-2017. *Denotes data not available; Table S2: Water quality variable measurements and number of samples available for each year $(\mathrm{N})$ of the Phongolo River measured at the Department of Water and Sanitation (DWS) monitoring station located below the Pongolapoort Dam wall (Downstream 1) from 1984-2017. * Denotes data not available; Table S3: Water quality variable measurements and number of samples available for each year $(\mathrm{N})$ of the Phongolo River measured at the Department of Water and Sanitation (DWS) monitoring station located within Ndumo Game Reserve (Downstream 2) from 1980-2017. *Denotes data not available; Table S4: Summary of the final scores allocated to water quality variables and the final PAI scores with associated present ecological state derived from water quality data collected from the three monitoring Department of Water and Sanitation (DWS) monitoring stations located above and below the Pongolapoort Dam. Upstream-Monitoring station located above the dam; Down 1-Monitoring station located below dam wall. Down 2-Monitoring station located within the Ndumo Game Reserve. Values 0-5 indicate amount of change from reference conditions. 0-No change, 1-Small change, 2-Moderate change, 3-Large change, 4-Serious change, 5-Extreme change; Table S5: Linear and generalised least squares regressions results assessing the effect of flow on all chemical water nutrient variables measured at the Department of Water and Sanitation (DWS) monitoring stations from 1985 to 2017 below the Pongolapoort Dam (Downstream 1). * Indicates significant effect; Table S6: Dunn's post hoc test analysis of significance results comparing Historic, Pre-drought (2009-2014) and Drought (2015-2017) chemical water nutrient variables measured at the Department of Water and Sanitation (DWS) monitoring station located upstream of the Pongolapoort Dam (Upstream); Table S7: Dunn's post hoc test analysis of significance results comparing Historic, Pre-drought (2009-2014) and Drought (2015-2017) chemical water nutrient variables measured at the Department of Water and Sanitation (DWS) monitoring station located below the Pongolapoort Dam wall (Downstream 1); Table S8: Dunn's post hoc test analysis of significance results comparing Historic, Pre-drought (2009-2014) and Drought (2015-2017) chemical water nutrient variables measured at the Department of Water and Sanitation (DWS) monitoring station located within Ndumo Game Reserve (Downstream 2).

Author Contributions: Conceptualization: R.G., V.W. and N.S.; Data curation: L.d.N. and T.N.; Formal analysis: L.d.N.; Funding acquisition: L.B., V.W. and N.S.; Investigation: L.d.N.; Supervision: R.G., J.v.V., L.B., V.W. and N.S.; Writing—Original draft: L.d.N.; Writing—Review \& editing: T.N., R.G., J.v.V., L.B., V.W. and N.S. All authors have read and agreed to the published version of the manuscript.

Funding: The financial assistance of the Deutscher Akademischer Austauschdienst (DAAD) and the National Research Foundation (NRF) towards this research is hereby acknowledged (Grant UID 105122). Opinions expressed, and conclusions arrived at, are those of the author and are not necessarily to be attributed to the NRF. This paper forms part of a Water Research Commission of South Africa funded study (Project K5-2185, PI: NJ Smit) and was co-funded by a VLIR-UOS TEAM project (ZEIN21013PR396, PI: L Brendonck and V Wepener).

Acknowledgments: The Department of Agriculture, Forestry and Fisheries (DAFF) of South Africa is hereby acknowledged for providing the data necessary to generate the site and irrigation map for this manuscript.

Conflicts of Interest: The authors declare no conflict of interest.

\section{References}

1. Khatri, N.; Tyagi, S. Influences of natural and anthropogenic factors on surface and groundwater quality in rural and urban areas. Front. Life Sci. 2015, 8, 23-39. [CrossRef]

2. Brainwood, M.A.; Burgin, S.; Maheshwari, B. Temporal variations in water quality of farm dams: Impacts of land use and water sources. Agric. Water Manag. 2004, 70, 151-175. [CrossRef]

3. Gerber, R.; Wepener, V.; Smit, N.J. Application of multivariate statistics and toxicity indices to evaluate the water quality suitability for fish of three rivers in the Kruger National Park, South Africa. Afr. J. Aquat. Sci. 2015, 3, 247-259. [CrossRef] 
4. Barakat, A.; El Baghdadi, M.; Rais, J.; Brahim, A.; Slassi, M. Assessment of spatial and seasonal water quality variation of Oum Er Rbia River (Morocco) using multivariate statistical techniques. Int. Soil Water Conserv. Res. 2016, 4, 284-292. [CrossRef]

5. Döll, P.; Fiedler, K.; Zhang, J. Global-scale analysis of river flow alterations due to water withdrawals and reservoirs. Hydrol. Earth Syst. Sci. 2009, 13, 2413-2432. [CrossRef]

6. Döll, P.; Zhang, J. Impact of climate change on freshwater ecosystems: A global-scale analysis of ecologically relevant river flow alterations. Hydrol. Earth Syst. Sci. 2010, 14, 783-799. [CrossRef]

7. Teodoru, C.; Wehrli, B. Retention of sediments and nutrients in the Iron Gate I Reservoir on the Danube River. Biogeochemistry 2005, 76, 539-565. [CrossRef]

8. Heath, S.K.; Plater, A.J. Records of pan (floodplain wetland). Sedimentation as an approach for post-hoc investigation of the hydrological impacts of dam impoundment: The Pongolo River, KwaZulu-Natal. Water Res. 2010, 44, 4226-4240. [CrossRef]

9. Marcinkowski, P.; Grygoruk, M. Long-term downstream effects of a dam on a lowland river flow regime: Case study of the Upper Narew. Water 2017, 9, 783. [CrossRef]

10. Sadaoui, M.; Ludwig, W.; Bourrin, F.; Bissonnais, Y.; Romero, E. Anthropogenic reservoirs of various sizes trap most of the sediment in the Mediterranean Maghreb Basin. Water 2018, 10, 927. [CrossRef]

11. Alcamo, J.; Flörke, M.; Märker, M. Future long-term changes in global water resources driven by socio-economic and climatic changes. Hydrol. Sci. J. 2007, 52, 247-275. [CrossRef]

12. Williams, G.P.; Wolman, M.G. Downstream Effects of Dams on Alluvial Rivers; Geological Survey Professional Paper 1286; US Government Printing Office: Washington, DC, USA, 1984.

13. Van Cappellen, P.; Maavara, T. Rivers in the Anthropocene: Global scale modifications of riverine nutrient fluxes by damming. Ecohydrol. Hydrobiol. 2016, 16, 106-111. [CrossRef]

14. Onyando, J.O.; Kisoyan, P.; Chemelil, M.C. Estimation of potential soil erosion for River Pekerra Catchment. Water Resour. Manag. 2005, 19, 133-143. [CrossRef]

15. Valentin, S.; Wasson, J.G.; Philippe, M. Effects of hydropower peaking on epilithon and invertebrate community trophic structure. Regul. Rivers Res. Manag. 1995, 10, 105-119. [CrossRef]

16. Cooper, A.R.; Infante, D.M.; Wherly, K.E.; Wang, L.; Brenden, T.O. Identifying indicators and quantifying large-scale effects of dams on fishes. Ecol. Indic. 2016, 16, 646-657. [CrossRef]

17. Tiemann, J.S.; Gillette, D.P.; Wildhaber, M.L.; Edds, D.R. Effects of lowhead dams on riffle-dwelling fishes and macroinvertebrates in a midwestern river. Trans. Am. Fish. Soc. 2004, 133, 705-717. [CrossRef]

18. Elosegi, A.; Díez, J.; Mutz, M. Effects of hydromorphological integrity on biodiversity and functioning of the river ecosystems. Hydrobiologia 2010, 657, 199-215. [CrossRef]

19. Buytaert, W.; Célleri, R.; de Bièvre, B.; Cisneros, F.; Wyseure, G.; Deckers, J.; Hofstede, R. Human impacts on the hydrology of the Andean páramos. Earth Sci. Rev. 2006, 79, 53-72. [CrossRef]

20. Dube, T.; de Necker, L.; van Vuren, J.H.J.; Wepener, V.; Smit, N.J.; Brendonck, L. Spatial and temporal variation of invertebrate community structure in flood-controlled tropical floodplain wetlands. J. Freshw. Ecol. 2016, 32, 1-15. [CrossRef]

21. Marcinkowski, P.; Grabowski, R.C.; Okruszko, T. Controls on anastomosis in lowland river systems: Towards process-based solutions to habitat conservation. Sci. Total Environ. 2017, 609, 1544-1555. [CrossRef]

22. Welcomme, R. Fisheries Ecology of Tropical Floodplain Rivers; Longman Press: London, UK, 1979.

23. Tockner, K.; Stanford, J.A. Riverine flood plains: Present state and future trends. Environ. Conserv. 2002, 29, 308-330. [CrossRef]

24. Bunn, S.E.; Arthington, A.H. Basic principles and ecological consequences of altered flow regimes for aquatic biodiversity. Environ. Manag. 2002, 30, 492-507. [CrossRef]

25. White, H.L.; Nichols, S.J.; Robinson, W.A.; Norris, R.H. More for less. A study of environmental flows during droughts in two Australian rivers. Freshw. Biol. 2012, 57, 858-873. [CrossRef]

26. Junk, W.J.; Bayley, P.B.; Sparks, R.E. The flood pulse concept in River-Floodplain-systems. Can. Spec. Publ. J. Fish. Aquat. Sci. 1989, 106, 110-127.

27. Davidson, T.A.; MacKay, A.W.; Wolski, P.; Mazebedi, R.; Murray-Hudson, T.M. Seasonal and spatial hydrological variability drives aquatic biodiversity in a flood-pulsed, subtropical wetland. Freshw. Biol. 2012, 57, 1253-1265. [CrossRef]

28. Lake, P.S. Ecological effects of perturbation by drought in flowing waters. Freshw. Biol. 2003, 48, 1161-1172. [CrossRef] 
29. Wood, P.J.; Armitage, P.D. The response of the macroinvertebrate community to low-flow variability and supra-seasonal drought within a groundwater dominated stream. Arch. Hydrobiol. 2004, 161, 1-20. [CrossRef]

30. Bond, N.R.; Lake, P.S.; Arthington, A.H. The impacts of drought on freshwater ecosystems: An Australian perspective. Hydrobiologia 2008, 600, 3-16. [CrossRef]

31. Chessman, B.C. Relationship between lotic macroinvertebrate traits and responses to extreme drought. Freshw. Biol. 2015, 60, 50-63. [CrossRef]

32. Mosley, L.M. Drought impacts on the water quality of freshwater systems; review and integration. Earth Sci. Rev. 2015, 140, 203-214. [CrossRef]

33. Chaparro, G.; Fontanarrosa, M.S.; O'Farrell, I. Colonization and succession of zooplankton after a drought: Influence of hydrology and free-floating plant dynamics in a floodplain lake. Wetlands 2016, 36, 85-100. [CrossRef]

34. Shabalala, A.N.; Combrinck, L.; McCrindle, R. Effects of farming activities on seasonal variation of water quality of Bonsma Dam, KwaZulu-Natal. S. Afr. J. Sci. 2013, 109, 1-7. [CrossRef]

35. Van der Laan, M.; van Antwerpen, R.; Bristow, K.L. River water quality in the northern sugarcane-producing regions of South Africa and implications for irrigation: A scoping study. Water SA 2012, 38, 87-96. [CrossRef]

36. Phocaides, A. Handbook on Pressurized Irrigation Techniques, 2nd ed.; Food and Agriculture Organization of the United Nations: Rome, Italy, 2007.

37. Simeonova, P.; Simeonov, V.; Andreev, G. Water quality study of the Struma River Basin, Bulgaria (1989-1998). Open Chem. 2003, 2, 121-136. [CrossRef]

38. Amatya, D.M.; Skaggs, R.W. Long-term hydrology and water quality of drained pine plantation in North Carolina. Trans. ASABE 2011, 54, 2087-2097. [CrossRef]

39. Rajeshwari, C.V.; Saraswathi, B. Assessment of water quality of Rivers Tungabhadra and Hundri, India. Pollut. Res. 2009, 28, 499-505.

40. Department of Water Affairs and Forestry (DWAF). South African Water Quality Guidelines, 1st ed.; Department of Water Affairs and Forestry: Pretoria, South Africa, 1996; Volume 8, Field Guide.

41. Zhang, Z.; Hibberd, A.; Zhou, J.L. Analysis of emerging contaminants in sewage effluent and river water: Comparison between spot and passive sampling. Anal. Chim. Acta 2008, 607, 37-44. [CrossRef]

42. Debels, P.; Figueria, R.; Urrutia, R.; Barra, R.; Niell, X. Evaluation of water quality in the Chillán River (Central Chile) using physicochemical parameters and a modified water quality index. Environ. Model Assess. 2005, 110, 301-322. [CrossRef]

43. Burt, T.P. Long-term study of the natural environment: Perceptive science or mindless monitoring? Prog. Phys. Geog. 1994, 18, 475-496. [CrossRef]

44. Burt, T.P.; Howden, N.J.K.; Worral, F.; Whelan, M.J. Long-term monitoring of river water nitrate: How much data do we need? J. Environ. Monit. 2010, 12, 71-79. [CrossRef]

45. Howden, N.J.K.; Burt, T.P.; Worral, F.; Whelan, M.J.; Bieroza, M. Nitrate concentrations and fluxes in the River Thames over 140 years (1868-2008): Are increases irreversible? Hydrol. Process. 2010, 23, 2657-2662. [CrossRef]

46. Burt, T.P.; Howden, N.J.K.; Worrall, F.; McDonnel, J.J. On the value of long-term, low-frequency water quality sampling: Avoiding throwing the baby out with the bathwater. Hydrol. Process. 2011, 25, 828-830. [CrossRef]

47. Yamazaki, Y.; Muneoka, T.; Okazawa, H.; Kimura, M.; Tsuji, O. Influence of the agricultural land agglomeration to the nutrients of the river water in the Tokachi River basin. Paddy Water Environ. 2017, 15, 277-290. [CrossRef]

48. Kavian, A.; Mohammadi, M.; Gholami, L.; Rodrigo-Comino, J. Assessment of the spatiotemporal effects of land use changes on runoff and nitrate loads in the Talar River. Water 2018, 1, 445. [CrossRef]

49. Alberto, W.D.; Del Pilar, D.M.; Valeria, A.M.; Fabiana, P.S.; Cecilia, H.A.; de Los Ángeles, B.B. Pattern recognition techniques for the evaluation of spatial and temporal variation in water quality. A case study: Suquia River Basin (Córdoba-Argentina). Water Res. 2001, 35, 2881-2894. [CrossRef]

50. Tomas, D.; Čurlin, M.; Marić, A.S. Assessing the surface water status in Pannonian ecoregion by the water quality index model. Ecol. Indic. 2017, 79, 182-190. [CrossRef]

51. Kleynhans, C.J.; Louw, M.D.; Thirion, C.; Rossouw, N.J.; Rowntree, K. River Ecoclassification: Manual for EcoStatus Determination (Version 1); WRC Report No. KV 168/05; Water Research Commission: Pretoria, South Africa, 2005. 
52. Department of Water Affairs and Forestry (DWAF). Methods for Determining the Water Quality Component of the Ecological Reserve; Department of Water Affairs: Pretoria, South Africa, 2008.

53. Kleynhans, C.J.; Louw, M.D.; Graham, M. Module G: EcoClassification and EcoStatus Determination in River EcoClassification: Index of Habitat Integrity (Section 1: Technical Manual); WRC Report No. TT 377-08; Water Research Commission: Pretoria, South Africa, 2008.

54. Barnes, K.; Ellery, W.; Kindness, A. A preliminary analysis of water chemistry of the Mkuze Wetland System, KwaZulu Natal: A mass balance approach. Water SA 2002, 28, 1-11. [CrossRef]

55. Shanyengana, E.S.; Seely, M.K.; Sanderson, R.D. Major-ion chemistry and ground water salinization in ephemeral floodplains in some arid regions of Namibia. J. Arid Environ. 2004, 57, 71-83. [CrossRef]

56. Singh, A.K.; Mondal, G.C.; Kumar, S.; Singh, T.B.; Tewary, B.K.; Sinha, A. Major ion chemistry, weathering processes and water quality assessment in upper catchment of Damodar River basin, India. Environ. Geol. 2008, 54, 745-758. [CrossRef]

57. Smit, N.J.; Vlok, W.; van Vuren, J.H.J.; du Preez, L.; van Eeden, E.; O’Brien, G.C.; Wepener, V. Socio-Ecological System Management of the Lower Phongolo River and Floodplain Using Relative Risk Methodology; WRC Report No. 2185/1/16; Water Research Commission: Pretoria, South Africa, 2016.

58. Jozini Municipality. Jozini Local Municipality Integrated Development Plan (IDP) 2017/18-2021/22. 4th Generation; Jozini Municipality: Jozini, South Africa, 2017.

59. Baudoin, M.A.; Vogel, C.; Nortje, N.; Naik, M. Living with drought in South Africa: Lessons learnt from the recent El Niño drought period. Int. J. Disaster Risk Reduct. 2017, 23, 128-137. [CrossRef]

60. Department of Water and Sanitation (DWS). Resource Directed Measures: Reserve Determination Study of Selected Surface Water and Groundwater Resources in the Usuthu/Mhlathuze Water Management Area. Pongola Floodplain—EWR Report—Hydrodynamic Modelling; Technical Report No. RDM/WMA6/CON/COMP/1213; Report compiled by Tlou Consulting (Pty) Ltd.: Pretoria, South Africa, 2014.

61. Dube, T.; Wepener, V.; van Vuren, J.H.J.; Smit, N.; Brendonck, L. The case for environmental flow determination for the Phongolo River, South Africa. Afr. J. Aquat. Sci. 2015, 40, 1-8. [CrossRef]

62. Department of Water and Sanitation (DWS). Resource Directed Measures: Reserve Determination Study of Selected Surface Water and Groundwater Resources in the Usutu/Mhlathuze Water Management Area. River Intermediate EWR_Volume 3: Specialist Reports; Report No. RDM/WMA6/CON/COMP/0813; Report compiled by Tlou Consulting (Pty) Ltd.: Pretoria, South Africa, 2014.

63. Heeg, J.; Breen, C.M. Man and the Pongolo Floodplain: A Report of the Committee for Inland Water Ecosystems, National Programme for Environmental Sciences; South African National Scientific Programmes Report No. 58; Cooperative Scientific Programmes, Council for Scientific and Industrial Research: Pretoria, South Africa, 1982.

64. Department of Water Affairs and Forestry (DWAF). The Effects of the Domoina Floods and Releases from the Pongolapoort Dam on the Pongola Floodplain; DWAF Report No. B-N3/0704/1; Department of Water Affairs: Pretoria, South Africa, 1985.

65. Hendriks, H.; Rossouw, J.N. Adopt-a-River Programme Phase II: Development of an Implementation Plan. Water Resource Quality Situation Assessment; Department of Water Affairs: Pretoria, South Africa, 2009.

66. Jaganyi, J.; Salagae, M.; Matiwane, N. Integrating Floodplain Livelihoods into a Diverse Rural Economy by Enhancing Co-Operative Management: A Case Study of the Pongolo Floodplain System, South Africa; WRC Report No. 1299/1/08; Water Research Commission: Pretoria, South Africa, 2009.

67. Smith, R.J.; Easton, J.; Nhancale, B.A.; Armstrong, A.J.; Cuverwell, J.; Dlamini, S.D.; Goodman, P.S.; Loffler, L.; Matthews, W.S.; Monadjem, A.; et al. Designing a Transfrontier conservation landscape for the Maputaland centre of endemism using biodiversity, economic and threat data. Biol. Conserv. 2008, 141, 2127-2138. [CrossRef]

68. Van Vuuren, L. Development steeped in controversy. Water Wheel 2009, 8, 23-27.

69. Coke, M. The water requirements of the Pongolo floodplain pas. In Proceedings of the Water Year 1970, Convention on Water for the Future, Pretoria, South Africa, 16-20 November 1970.

70. Coke, M. The Status of the Pongolo Floodplain Pans and the Effect of a 1000 Cumec Flood in December 1970; Unpublished Report; Natal Parks, Game and Fish Preservation Board: Pietermaritzburg, South Africa, 1970.

71. Heeg, J.; Breen, C.M.; Rodgers, K.H. The Pongolo floodplain: A unique ecosystem threatened. Civil. Eng. South Afr. 1980, 22, 125-128.

72. Merron, G.S.; Bruton, M.; de Lalouvriere, P.L.H. Changes in fish communities of the Phongolo floodplain, Zululand (South Africa) before, during and after a severe drought. Regul. River. 1993, 8, 335-344. [CrossRef] 
73. Merron, G.S.; Bruton, M.; de Lalouvriere, P.L.H. Implications of water release from the Pongolapoort Dam for the fish and fishery of the Phongolo floodplain, Zululand. Afr. J. Aquat. Sci. 1993, 19, 34-49. [CrossRef]

74. South African Wetlands Conservation Programme (SA Wetlands Conservation Programme). Ndumo Game Reserve, South Africa, Information Sheet; Document No: 24/21/3/3/3/15; Department of Environmental Affairs and Tourism: Pretoria, South Africa, 1996.

75. Ndumo Game Reserve: Integrated Management Plan: 2009-2013 (Version 1.0); Ezemvelo KZN Wildlife: Pietermaritzburg, South Africa, 2009.

76. Holloway, A. Drought emergency, yes... drought disaster, no: Southern Africa 1991-93. Camb. Rev. Int. Aff. 2000, 14, 254-276. [CrossRef]

77. Rouault, M.; Richard, M. Intensity and spatial extension of drought in South Africa at different time scales. Intensity and spatial extension of drought in South Africa at different time scales. Water SA 2003, 29, 489-500.

78. Kovaçs, Z.P.; du Plessis, D.B.; Bracher, P.R.; Dunn, P.; Mallory, G.C.L. Documentation of the 1984 Domoina Floods; Technical Report No. TR122; Department of Water Affairs: Pretoria, South Africa, 1985.

79. Bence, J.R. Analysis of short time series: Correcting for autocorrelation. Ecology 1995, 76, 628-639. [CrossRef]

80. Yue, S.; Pilon, P.; Phinney, B.; Cavadias, G. The influence of autocorrelation on the ability to detect trend in hydrological series. Hydrol. Process. 2002, 16, 1807-1829. [CrossRef]

81. Zuur, A.F.; Ieno, E.N.; Walker, N.J.; Saveliev, A.A.; Smith, G.M. Mixed Effects Models and Extensions in Ecology with R; Springer: New York, NY, USA, 2009.

82. Warton, D.I.; Hui, F.K. The arcsine is asinine: The analysis of proportions in ecology. Ecology 2015, 92, 3-10. [CrossRef]

83. Guareschi, S.; Abellán, P.; Laini, A.; Green, A.J.; Sánchez-Zapata, J.A.; Velasco, J. Cross-taxon congruence in wetlands: Assessing the value of waterbirds as surrogates of macroinvertebrate biodiversity in Mediterranean Ramsar sites. Ecol. Indic. 2015, 49, 204-215. [CrossRef]

84. Du Preez, G.C.; Wepener, V.; Fourie, H.; Daneel, M.S. Irrigation water quality and the threat it poses to crop production: Evaluating the status of the Crocodile (West) and Marico catchments, South Africa. Environ. Monit. Assess. 2018, 190, 127. [CrossRef]

85. Singh, K.P.; Malik, A.; Mohan, D.; Sinha, S. Multivariate statistical techniques for the evaluation of spatial and temporal variations in water quality of Gomti River (India) -A case study. Water Res. 2004, 38, 3980-3992. [CrossRef]

86. Zeinalzadeh, K.; Rezaei, E. Determining spatial and temporal changes of surface water quality using principal component analysis. J. Hydrol. Reg. Stud. 2017, 13,1-10. [CrossRef]

87. Šmilauer, P.; Lepš, J. Multivariate Analysis of Ecological Data Using Canoco 5; Cambridge University Press: Cambridge, UK, 2014.

88. Kleynhans, C.J.; Louw, M.D. River EcoClassification: Manual for EcoStatus Determination (Version 2), Module A: EcoClassification and EcoStatus Determination; WRC Report No. TT 329/8; Water Research Commission: Pretoria, South Africa, 2008.

89. Lankford, B.; Pringle, C.; Dickens, C.; Lewis, F.; Mander, M.; Chhotray, V.; Goulden, M.; Nxele, Z.; Quayle, L. Hydrological modelling of water allocation, ecosystem services and poverty alleviation in the Pongola floodplain, South Africa. J. Environ. Plan. Manag. 2011, 54, 1237-1260. [CrossRef]

90. Witt, H.; Patel, R.; Schnurr, M. Can the poor help GM crops? Technology, representation and cotton in the Makhathini flats, South Africa. Rev. Afr. Political Econ. 2006, 109, 497-513. [CrossRef]

91. Tiwari, R.K. Environmental impact of coal mining on water regime and its management. Water Air Soil Poll. 2001, 131, 185-199. [CrossRef]

92. Ahearn, D.S.; Sheibley, R.W.; Dahlgren, R.A. Effects of river regulation on water quality in the lower Mokelumne River, California. River Res. Appl. 2005, 21, 651-670. [CrossRef]

93. Hu, Q.; Yang, Y.; Han, S.; Yang, Y.; Ai, Z.; Wang, J.; Ma, F. Identifying changes in irrigation return flow with gradually intensified water-saving technology using HYDRUS for regional water resources management. Agr. Water Manag. 2017, 194, 33-47. [CrossRef]

94. Merchán, D.; Causapé, J.; Abrahão, R.; García-Garizábal, I. Assessment of a newly implemented irrigated area (Lerma Basin, Spain) over a 10-year period. II: Salts and nitrate exported. Agr. Water Manag. 2015, 158, 288-296. [CrossRef]

95. Department of Water Affairs and Forestry (DWAF). South African Water Quality Guidelines, 2nd ed.; Department of Water Affairs and Forestry: Pretoria, South Africa, 1996; Volume 1, Domestic Use. 
96. Walling, D.E.; Fang, D. Recent trends in the suspended sediment loads of the world's rivers. Glob. Planet. Chang. 2003, 39, 111-126. [CrossRef]

97. Kelly, V.J. Influence of reservoirs on solute transport: A regional-scale approach. Hydrol. Process. 2001, 15, 1227-1249. [CrossRef]

98. Harrison, J.A.; Maranger, R.J.; Alexander, R.B.; Giblin, A.E.; Jacinthe, P.A.; Mayorga, E.; Seitzinger, S.P.; Sobota, D.J.; Wollheim, W.M. The regional and global significance of nitrogen removal in lakes and reservoirs. Biogeochemistry 2009, 97, 143-157. [CrossRef]

99. Heeg, J.; Breen, C. Resolution of conflicting values on the Pongola River floodplain. In Wetlands and Shallow Continental Water Bodies; Patten, B., Jorgenson, S., Dumont, S., Eds.; SBP Publishing: The Hague, The Netherlands, 1994; Volume 2, pp. 303-359.

100. Zeng, L.; McGowan, S.; Cao, Y.; Chen, X. Effects of dam construction and increasing pollutants on the ecohydrological evolution of a shallow freshwater lake in the Yangtze floodplain. Sci. Total Environ. 2018, 621, 219-227. [CrossRef]

101. González, J.M.; Mollá, S.; Roblas, N.; Descals, E.; Moya, Ó.; Casado, C. Small dams decrease leaf litter breakdown rates in Mediterranean mountain streams. Hydrobiologia 2013, 712, 117-128. [CrossRef]

102. Ewart-Smith, J.; Ollis, D.; Day, J.A.; Malan, H. National Wetland Inventory: Development of a Wetland Classification System for South Africa; Technical Report No. K8/652; Prepared for: Water Research Commission (WRC): Pretoria, South Africa; the South African National Biodiversity Institute (SANBI): Pretoria, South Africa, 2006.

103. Nahlik, A.M.; Mitsch, W.J. The effects of river pulsing on sedimentation and nutrients in created riparian wetlands. J. Environ. Qual. 2008, 37, 1634-1643. [CrossRef]

104. Friedl, G.; Wüest, A. Disrupting biogeochemical cycles-Consequences of damming. Aquat. Sci. 2002, 64, 55-65. [CrossRef]

105. Humborg, C.; Conley, D.J.; Rahm, L.; Wulff, F.; Cociasu, A.; Itteko, V. Silicon retention in River Basins: Far-reaching effects on biogeochemistry and aquatic food webs in coastal marine environments. AMBIO 2000, 29, 45-50. [CrossRef]

106. Akhurst, E.G.J.; Breen, C.M. Ionic content as a factor influencing turbidity in two floodplain lakes after a flood. Hydrobiologia 1988, 160, 19-31. [CrossRef]

107. Tooth, S.; McCarthy, T.S. Wetlands in drylands: Geomorphological and sedimentological characteristics, with emphasis on examples from southern Africa. Prog. Phys. Geog. 2007, 31, 3-41. [CrossRef] 